\title{
Proteome analysis of Aspergillus niger: Lactate added in starch-containing medium can increase production of the mycotoxin fumonisin $B_{\mathbf{2}}$ by modifying acetyl-CoA metabolism Louise M Sørensen*1,2, Rene Lametsch ${ }^{2}$, Mikael R Andersen ${ }^{1}$, Per V Nielsen ${ }^{3}$ and Jens C Frisvad ${ }^{1}$
}

Addresses: ${ }^{1}$ Department of Systems Biology, Søltofts Plads, Technical University of Denmark, DK-2800 Kgs Lyngby, Denmark, ${ }^{2}$ Department of Food Science, Faculty of Life Sciences, University of Copenhagen, Rolighedsvej 30, DK-1958 Frederiksberg C, Denmark and ${ }^{3}$ IPU, Produktionstorvet, building 425, DK-2800 Kgs Lyngby, Denmark

E-mail: Louise M Sørensen* - Ims@life.ku.dk; Rene Lametsch - rla@life.ku.dk; Mikael R Andersen - mr@bio.dtu.dk; Per V Nielsen - pvn@ipu.dk; Jens C Frisvad - jcf@bio.dtu.dk

*Corresponding author

Published: 10 December 2009

BMC Microbiology 2009, 9:255

oi: $10.1|86 /| 47|-2| 80-9-255$
Received: 17 May 2009

Accepted: 10 December 2009

This article is available from: http://www.biomedcentral.com/I47|-2/80/9/255

(C) 2009 Sørensen et al; licensee BioMed Central Ltd.

This is an Open Access article distributed under the terms of the Creative Commons Attribution License (http://creativecommons.org/licenses/by/2.0), which permits unrestricted use, distribution, and reproduction in any medium, provided the original work is properly cited.

\begin{abstract}
Background: Aspergillus niger is a filamentous fungus found in the environment, on foods and feeds and is used as host for production of organic acids, enzymes and proteins. The mycotoxin fumonisin $B_{2}$ was recently found to be produced by $A$. niger and hence very little is known about production and regulation of this metabolite. Proteome analysis was used with the purpose to reveal how fumonisin $B_{2}$ production by $A$. niger is influenced by starch and lactate in the medium.

Results: Fumonisin $B_{2}$ production by $A$. niger was significantly increased when lactate and starch were combined in the medium. Production of a few other $A$. niger secondary metabolites was affected similarly by lactate and starch (fumonisin $B_{4}$, orlandin, desmethylkotanin and pyranonigrin $A$ ), while production of others was not (ochratoxin $A$, ochratoxin alpha, malformin $A$, malformin $C$, kotanin, aurasperone $B$ and tensidol $B$ ). The proteome of $A$. niger was clearly different during growth on media containing $3 \%$ starch, $3 \%$ starch $+3 \%$ lactate or $3 \%$ lactate. The identity of 59 spots was obtained, mainly those showing higher or lower expression levels on medium with starch and lactate. Many of them were enzymes in primary metabolism and other processes that affect the intracellular level of acetyl-CoA or NADPH. This included enzymes in the pentose phosphate pathway, pyruvate metabolism, the tricarboxylic acid cycle, ammonium assimilation, fatty acid biosynthesis and oxidative stress protection.

Conclusions: Lactate added in a medium containing nitrate and starch can increase fumonisin $B_{2}$ production by $A$. niger as well as production of some other secondary metabolites. Changes in the balance of intracellular metabolites towards a higher level of carbon passing through acetyl-CoA and a high capacity to regenerate NADPH during growth on medium with starch and lactate were found to be the likely cause of this effect. The results lead to the hypothesis that fumonisin production by $A$. niger is regulated by acetyl-CoA.
\end{abstract}




\section{Background}

Aspergillus niger is a versatile filamentous fungus found in the environment all over the world in soil and on decaying plant material and it has been reported to grow on a large number of foods and feeds [1]. At the same time it is a popular production host for industrial fermentations and it is used for production of both organic acids and for indigenous and heterologous enzymes and proteins [2-4]. However, A. niger produces various secondary metabolites, and among those also the important mycotoxins fumonisin $\mathrm{B}_{2}\left(\mathrm{FB}_{2}\right)$ and ochratoxin A (OTA) $[5,6]$. Due to the ubiquity of $A$. niger, its production of secondary metabolites is important both from a biotechnological and a food-safety viewpoint.

Secondary metabolites are small molecules that are not directly involved in metabolism and growth. Both plants and fungi are known for producing a large number of chemically diverse secondary metabolites. While the role of some of these metabolites makes sense biologically as inferring an advantage to the producer, e.g. antibiotics, virulence factors, siderophores and pigments, the benefit of others is less obvious or unknown. The general belief is that the secondary metabolites must contribute to the survival of the producer in its environment where it competes with other organisms [7]. Whereas the ability to produce individual secondary metabolites is speciesspecific, the actual production of secondary metabolites has, in broad terms, been reported to be affected by the developmental stage of the fungus (i.e. conidiation) and intrinsic and extrinsic factors of the environment as substrate (composition, $\mathrm{pH}$, water activity), temperature, light and oxygen availability [8-12].

Fumonisins are a group of secondary metabolites with a highly reduced polyketide-derived structure consisting of a hydrocarbon backbone with an amino group in one end, some methyl groups and two ester-bound side groups consisting of tricarballylic acid moieties. The fumonisin B-series group contains up to three hydroxyl groups and the degree of hydroxylation gives rise to the designations $\mathrm{B}_{1}-\mathrm{B}_{4}[13,14]$. These are classified as mycotoxins as they have been shown to be cytotoxic and carcinogenic $[14,15]$ and fumonisins have been suspected to be involved in oesophageal cancer in South Africa and China [16-19]. Fumonisin production in Fusarium spp. has been known since the 1980's [20], while the ability of $A$. niger to produce $\mathrm{FB}_{2}$ was just discovered in 2007 based on indications from the genome sequencing projects of $A$. niger ATCC 1015 and CBS $513.88[6,21,22]$. The fumonisin biosynthesis pathway and the gene cluster are partly characterized in $F$. verticillioides and include a polyketide synthase (Fum1), fatty acyl-CoA synthetases (Fum10, Fum16), an aminotransferase (Fum8), a short chain dehydrogenase/ reductase (Fum13), cytochome P450 monooxygenases (Fum6, Fum12 and/or Fum15) and a dioxygenase (Fum9) [23]. The expected fumonisin biosynthesis gene cluster in the A. niger CBS 513.88 genome contains 14 open reading frames of which a number has similarity to the fumonisin biosynthesis cluster genes in F. verticillioides [22]. Although the knowledge of the biosynthesis pathway is incomplete, the expected precursors and cofactors required for production of fumonisins are acetyl-CoA, malonyl-CoA, methionine, alanine, 2-ketoglutarate, $\mathrm{O}_{2}$ and NADPH [13].

Due to the late discovery of $\mathrm{FB}_{2}$ production in A. niger, its ability to produce this metabolite has only been the subject of a few studies. A. niger was shown to be a relatively consistent producer of $\mathrm{FB}_{2}$ on media such as Czapek yeast autolysate agar (CYA) with $5 \% \mathrm{NaCl}$ $[6,24]$, yet it was noted that the media that support $\mathrm{FB}_{2}$ production in $A$. niger were different from those who were supportive in F. verticillioides [6].

To evaluate the potential risk of mycotoxin production in foods and feeds, we explored the influence of substrate on $\mathrm{FB}_{2}$ production by $A$. niger. During our screening of food-related carbon sources as glucose, sucrose, lactate, starch and fat we found that lactate, when added to a medium containing starch, could synergistically increase the $\mathrm{FB}_{2}$ production compared to either starch or lactate alone. To reveal a biological explanation for this interesting observation, we combined growth physiology studies including measurement of several secondary metabolites with a proteome study.

Proteome studies give information about the capability for metabolic flow in the cell, for maintenance of the cell and for anabolic and catabolic processes. The proteome constitutes the cellular machinery, is energetically expensive to maintain and has a crucial influence on the fitness of the fungus. Protein synthesis and degradation are thus carefully regulated at multiple levels. The use of proteome analysis within studies of filamentous fungi has attracted increasing interest in these years and has recently been reviewed by Carberry and Doyle [25], Kim et al. [26,27] and Andersen and Nielsen [28]. The emergence of fungal genome sequences combined with continuously improved mass spectrometry technologies will further show proteomics as useful for studies in fungal biology.

We report on a $2 \mathrm{D}$ gel based proteome study conducted to relate differences in protein levels with differences in secondary metabolites especially $\mathrm{FB}_{2}$ production, and with the aim of elaborating on the reasons for an increased $\mathrm{FB}_{2}$ production on medium containing starch in combination with lactate. 


\section{Results and discussion}

\section{Growth and secondary metabolite production}

For these experiments we used a wildtype A. niger isolate (A. niger IBT 28144) that is able to carry out normal metabolism and synthesis essential for growth and survival in a natural habitat. Additionally it was able to produce both of the two mycotoxins $\mathrm{FB}_{2}$ and OTA. With the aim to explore factors that influence secondary metabolism, especially $\mathrm{FB}_{2}$ biosynthesis, we used this isolate, grown on the surface of a solid medium and with a moderately rich substrate containing amino acids, nitrate, vitamins, minerals, trace metals and the polysaccharide starch (Czapek Yeast Autolysate agar with saccharose replaced by starch and/or other carbon sources). A. niger IBT 28144 grew vigorously under these conditions (Figure 1). Mycelium was observed 20 hours after inoculation and biomass accumulated within 70 hours. Aerial hyphae, the first sign of onset of conidiation, were observed already after 24 hours.

To measure the production of secondary metabolites we used a modified version of a micro-scale extraction procedure [29] that is suitable for detection of a wide array of metabolites. Using plug sampling, the amount of secondary metabolites was determined per surface area of the culture including both metabolites within the cells and metabolites diffusing into the medium. Using this method we detected the following metabolites produced by $A$. niger on starch-containing medium; fumonisin $\mathrm{B}_{2}$, fumonisin $\mathrm{B}_{4}$, ochratoxin $\mathrm{A}$, ochratoxin alpha, malformin A, malformin C, orlandin, desmethylkotanin, kotanin, aurasperone $\mathrm{B}$, pyranonigrin $\mathrm{A}$ and tensidol $\mathrm{B}$.

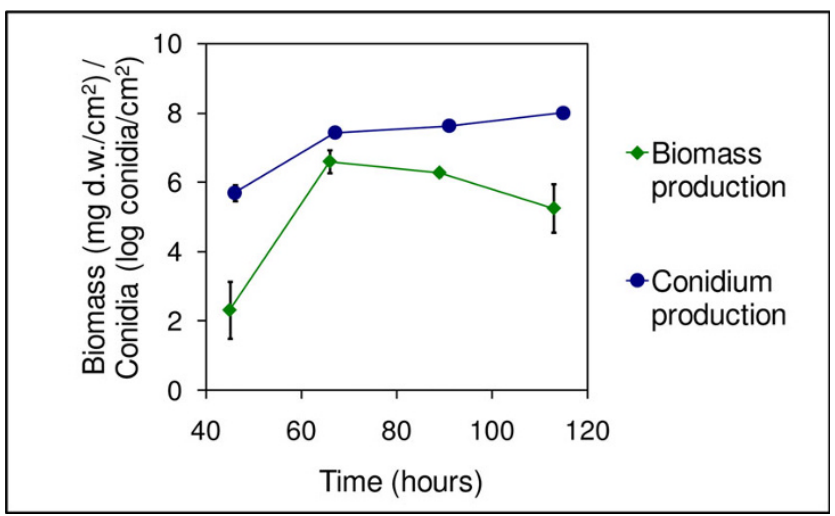

Figure I

Growth and conidium production. Growth measured as biomass production ( $\mathrm{mg}$ dry weigth $/ \mathrm{cm}^{2}$ ) and conidium production (log conidia/ $\mathrm{cm}^{2}$ ) by A. niger IBT 28144 on medium containing $3 \%$ starch. Average values \pm standard deviations $(n=3-6)$.
Presence of lactate, which may be encountered in environments with fermenting microorganisms and especially in fermented food products, was found to increase $\mathrm{FB}_{2}$ production considerably when supplied in tandem with starch. The $\mathrm{FB}_{2}$ levels detected on media with 3\% starch plus 3\% lactate were 2-3 times higher than the levels on 3\% starch. The differences were significant (95\% confidence) at the samplings 66, 92 and 118 hours after inoculation (Figure 2). The stimulating effect of lactate on $\mathrm{FB}_{2}$ production seemed to be proportional to the concentration of lactate as $3 \%$ starch plus $1.5 \%$ lactate resulted in levels intermediate of those containing 3\% starch and either no lactate or $3 \%$ lactate. Fumonisin $\mathrm{B}_{4}$, orlandin, desmethylkotanin and pyranonigrin $\mathrm{A}$ were regulated like $\mathrm{FB}_{2}$ but only during the later growth phase (Figure 3). Especially the level of the polyketide orlandin was increased synergistically by the combination of starch and lactate. Orlandin, desmethylkotanin and kotanin have very similar polyketide structures and are expected to be part of the same biosynthesis pathway [30], but kotanin was not influenced in the same way as orlandin and desmethylkotanin by presence of starch and lactate. The differential influence of starch and lactate on production of the 12 measured metabolites indicates that secondary metabolism of $A$. niger is not restricted to a common regulation under these conditions. Presence of starch was important for both the growth and the production of secondary metabolites; all were lower on 3\% lactate compared to $3 \%$ starch with the exception of the ochratoxins that were produced at similar amounts on lactate and starch.

We considered whether the effect of lactate in combination with starch could be due to a specific induction of secondary metabolite synthesis by lactate and if this

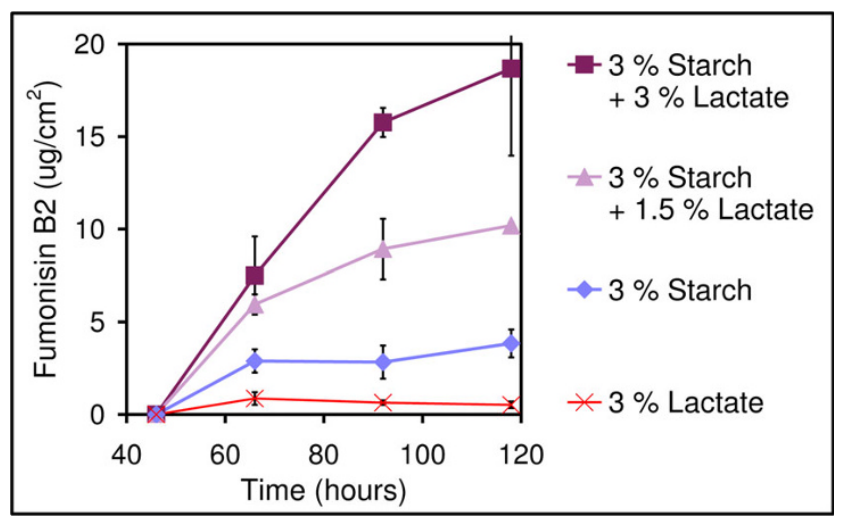

Figure 2

Fumonisin $\mathbf{B}_{\mathbf{2}}$ production. Levels of fumonisin $\mathrm{B}_{2}\left(\mu \mathrm{g} / \mathrm{cm}^{2}\right)$ produced by $A$. niger IBT 28 I 44 on media containing $3 \%$ lactate, $3 \%$ starch, $3 \%$ starch $+1.5 \%$ lactate and $3 \%$ starch + $3 \%$ lactate. Average values \pm standard deviations $(n=3-18)$. 

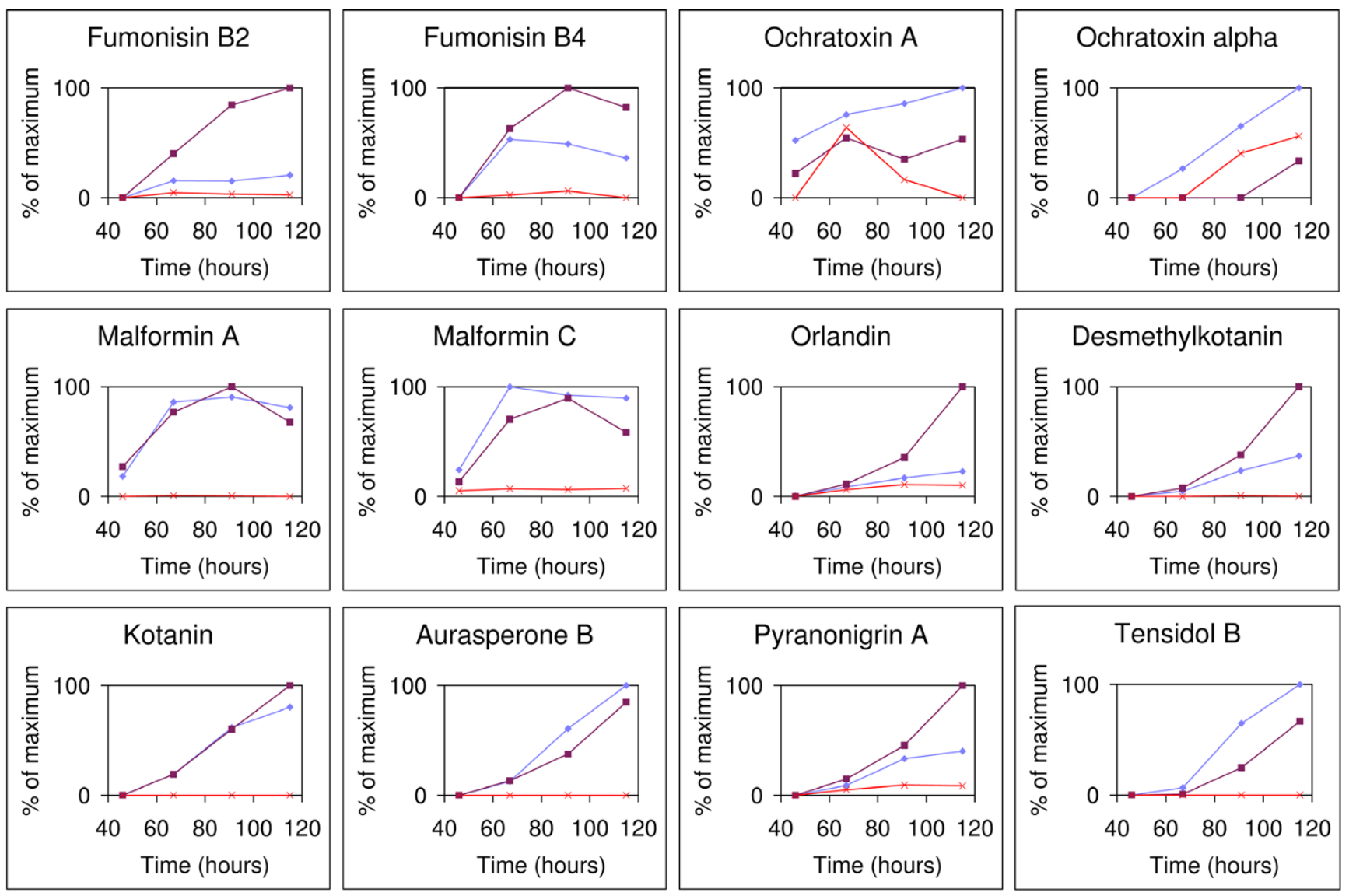

$-3 \%$ Starch

$-3 \%$ Starch $+3 \%$ Lactate

$\star 3 \%$ Lactate

\section{Figure 3}

Secondary metabolite production. Production of selected secondary metabolites produced by A. niger IBT 28 I 44 on media containing 3\% starch, $3 \%$ starch $+3 \%$ lactate and 3\% lactate. Data based on average peak area per $\mathrm{cm}^{2}(\mathrm{n}=3) \mathrm{calculated}$ as percentage of maximum value obtained for each metabolite.

could constitute some kind of antimicrobial defence. However we found that pyruvate, a product of L-lactate degradation (eq. 1 and 2), had a similar effect (Table 1), which makes an effect of lactate itself unlikely and to a higher degree pointing to an effect of lactate degradation.

While it is well known that starch is degraded by extracellular enzymes to maltose and glucose, transported into the cell and then entering glycolysis, we may assume that lactate is transported into the cell by a lactate transporter and mainly metabolized further to pyruvate by a L-lactate dehydrogenase (EC 1.1.1.27) or a L-lactate dehydrogenase (cytochrome) (EC 1.1.2.3), both are predicted to be present in the genome. While the medium with $3 \%$ starch $+3 \%$ lactate contains approximately the double amount of added carbon source (the yeast extract contains carbon sources as well) compared to the media with $3 \%$ starch or $3 \%$ lactate alone, it is possible that this
Table I: Fumonisin $\mathbf{B}_{\mathbf{2}}$ production on different carbon sources

\begin{tabular}{lll}
\hline Supplemented carbon source & Fumonisin $\mathbf{B}_{\mathbf{2}}{ }^{\mathbf{1 , 2}}\left(\boldsymbol{\mu g} / \mathbf{c m}^{\mathbf{2}}\right)$ & $\mathbf{n}^{\mathbf{3}}$ \\
\hline $3 \%$ Starch & $2.89 \pm 0.63^{\mathrm{a}}$ & 18 \\
$3 \%$ Starch $+3 \%$ maltose & $2.61 \pm 0.74^{\mathrm{a}}$ & 3 \\
$3 \%$ Starch $+3 \%$ xylose & $2.06 \pm 0.28^{\mathrm{a}}$ & 3 \\
$3 \%$ Starch $+3 \%$ lactate & $7.49 \pm 2.10^{\mathrm{b}}$ & 14 \\
$3 \%$ Starch $+3 \%$ pyruvate & $5.06 \pm 0.60^{\mathrm{b}}$ & 3 \\
$3 \%$ Lactate & $0.86 \pm 0.34^{\mathrm{c}}$ & 15 \\
\hline
\end{tabular}

I) $\mathrm{FB}_{2}$ produced (average \pm standard deviation) by A. niger IBT 28 I 44 after 66-67 hours on media supplemented with the indicated carbon sources.

2) Different letters indicate statistically significant differences using Fisher's least significant difference procedure (95\% confidence).

3) Number of replicates.

is partly counteracted by carbon catabolite repression of the lactate transporter, as the activity of the lactate transporter in yeast, Jen $1 \mathrm{p}$, is inversely related to the 
concentration of repressing sugar [31]. The available energy contributed from $3 \%$ lactate is expected to be a bit lower than from $3 \%$ starch, as less ATP is generated from 2 lactate (eq. 1 and 2) than from 1 glucose (eq. 3). But, this is based on the assumption that a full conversion of starch to glucose occurs and that glucose is not turned into energy storage metabolites as trehalose or polyols, as it does during liquid culture conditions [32].

$$
\begin{gathered}
\text { L-Lactate }+\mathrm{NAD}^{+} \rightarrow \text { Pyruvate }+\mathrm{NADH}+\mathrm{H}^{+} \\
\text {L-Lactate } \rightarrow \text { Pyruvate }+2 \mathrm{e}^{-}+2 \mathrm{H}^{+}
\end{gathered}
$$

$1 / 2$ D-Glucose $+\mathrm{NAD}^{+}+\mathrm{P}_{\mathrm{i}}+\mathrm{ADP} \rightarrow \rightarrow \rightarrow$ Pyruvate $+\mathrm{NADH}+\mathrm{ATP}$

In practice, we observed a low biomass production (mg dry weight $/ \mathrm{cm}^{2}$ ) on the medium with $3 \%$ lactate, while the produced biomass on media containing 3\% starch with or without additional 3\% lactate was not significantly different. Although the presence of starch was important for both growth and $\mathrm{FB}_{2}$ production of $A$. niger, addition of either $3 \%$ maltose or $3 \%$ xylose to medium containing 3\% starch did not further increase the $\mathrm{FB}_{2}$ production. The effect of added lactate can consequently not be a simple result of a double amount of carbon source.

\section{Exploring the proteome}

Proteome analysis was conducted in order to identify proteins for which expression levels were altered during growth of $A$. niger on media containing 3\% starch (S), $3 \%$ starch $+3 \%$ lactate (SL) and 3\% lactate (L), and if possible relate the identified proteins to the influence on $\mathrm{FB}_{2}$ production. The samples for protein extraction were taken 60 hours after inoculation as the $\mathrm{FB}_{2}$ production rate was estimated to be highest at this time. In order to document $\mathrm{FB}_{2}$ synthesis, $\mathrm{FB}_{2}$ production was measured after 58 hours and 66 hours. The $\mathrm{FB}_{2}$ synthesis rate was calculated to be (average $\pm 95 \%$ confidence limits, $n=6$ ) $280 \pm 140 \mathrm{ng} / \mathrm{cm}^{2} / \mathrm{h}$ on S, $520 \pm 90 \mathrm{ng} / \mathrm{cm}^{2} / \mathrm{h}$ on SL and $10 \pm 60 \mathrm{ng} / \mathrm{cm}^{2} / \mathrm{h}$ on L. Biomass (dry weight) was measured after 62 hours and was (average \pm standard deviations, $\mathrm{n}=3$ ) $6.2 \pm 0.4 \mathrm{mg} / \mathrm{cm}^{2}$ on $\mathrm{S}, 6.5 \pm 1.0 \mathrm{mg} /$ $\mathrm{cm}^{2}$ on SL and $1.3 \pm 0.3 \mathrm{mg} / \mathrm{cm}^{2}$ on $\mathrm{L}$.

Extracted proteins were separated by two-dimensional polyacrylamide gel electrophoresis (Figure 4). On 18 gels, representing 2 biological replicates and 3 technical replicates of $A$. niger cultures on each of the media $\mathrm{S}, \mathrm{SL}$ and $\mathrm{L}$, we detected 536-721 spots. With regard to the size of gels and amount of loaded protein, this was comparable to detected spots in other proteome studies of intracellular proteins in Aspergillus [33,34]. One protein was present at very high levels on the media containing starch, which was identified as glucoamylase [Swiss-Prot: P69328]. Jorgensen et al. [35] did similarly find this protein to have the highest transcript level of all genes in a transcriptome analysis of $A$. niger on maltose. Because of the volume and diffusion of this spot, the area containing this spot was excluded from the data analysis. About $80 \%$ of the spots were matched to spots on a reference gel containing a mixture of all samples. Thus, the total dataset for further analysis consisted of 649 matched spots (see Additional file 1).

Large differences in the proteome of A. niger when grown on S, SL and L were evident. A principal component analysis (PCA) clearly separated the gels with proteins from each media into three separate groups (Figure 5). The largest variance in relative spot volume was between samples from media with or without presence of starch ( $1^{\text {st }}$ component), while the next-largest variance in relative spot volume separated samples from $S$ and SL $\left(2^{\text {nd }}\right.$ component). Statistically, $36 \%$ of the spots were present at significantly different levels between two or all three of the treatments (two-sided Students t-test, 95\% confidence). Clustering of the 649 spots according to their relative spot volume by consensus clustering [36] resulted in prediction of 39 clusters. More than half of the spots were in clusters with a clear influence of medium on the protein level (18 clusters corresponding to $53 \%$ of the spots, Table 2) and 130 spots were in clusters with protein levels affected specifically on SL (cluster (cl.) 4, 7, 8, 35, 36, 37, 38).

The spots to be identified were selected within clusters with a profile with either distinct or tendency for higher (Table 3) or lower (Table 4) protein levels on SL compared to on $\mathrm{S}$ and $\mathrm{L}$ as these correlated positively or negatively with $\mathrm{FB}_{2}$ production. Also some spots with levels influenced by presence of starch (Table 5) or lactate (Table 6) with either distinct or highly abundant presence on the gels were selected. Spots present at significant different levels between the two or three treatments were preferred. A total of 59 spots were identified using in-gel trypsin digestion to peptides, MALDI TOF/TOF and Mascot searches of retrieved MS/ MS spectra to sequences from the databases Swiss-Prot [37] or NCBInr [38]. We did not use any taxonomic restrictions, however all except one protein were confidently identified as A. niger (predicted) proteins. One protein (6715) that did not match an A. niger protein, probably because it was missed or truncated during sequencing, had a significant match to a protein from N. crassa [UniProt: NCU04657]. Only 6 proteins (8 spots) were identified as proteins in the Swiss-Prot database and thus regarded as fully characterised. Otherwise, the proteins were registered in the NCBInr database as it contains the protein entries predicted from 


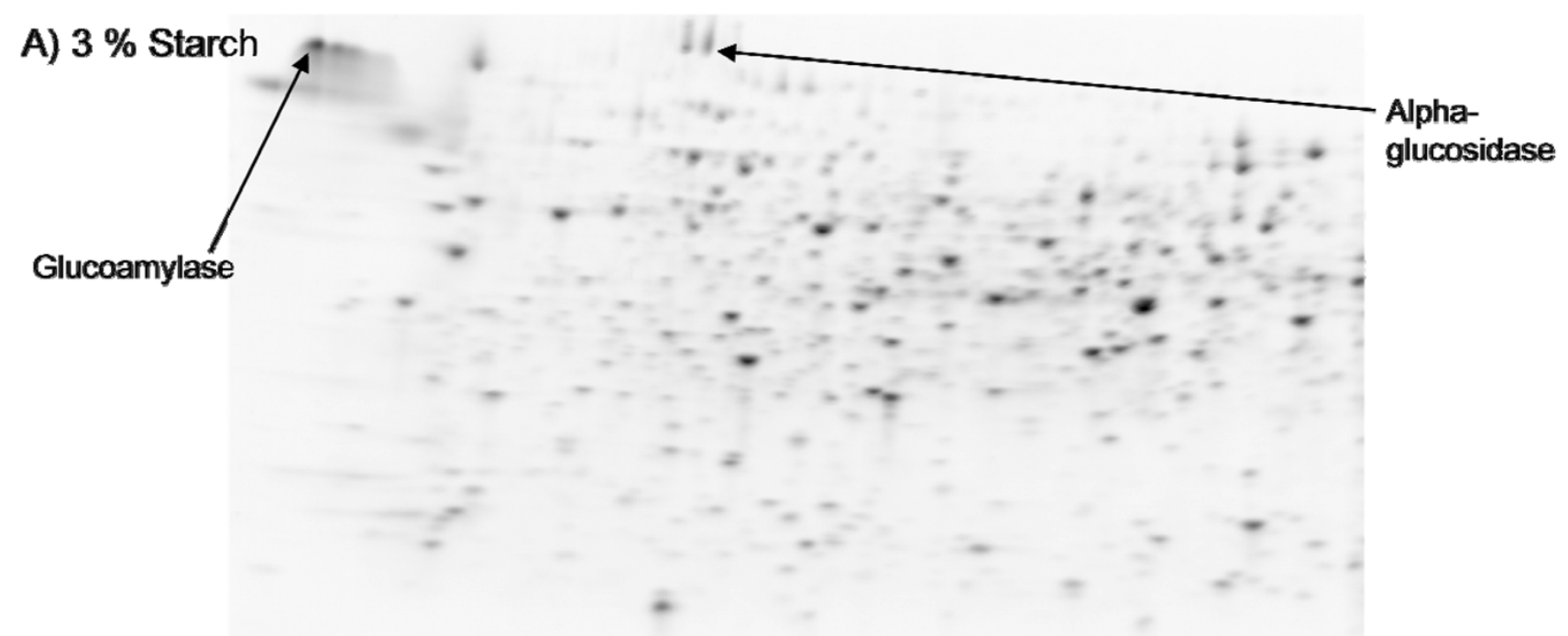

B) $3 \%$ Starch $+3 \%$ lactate

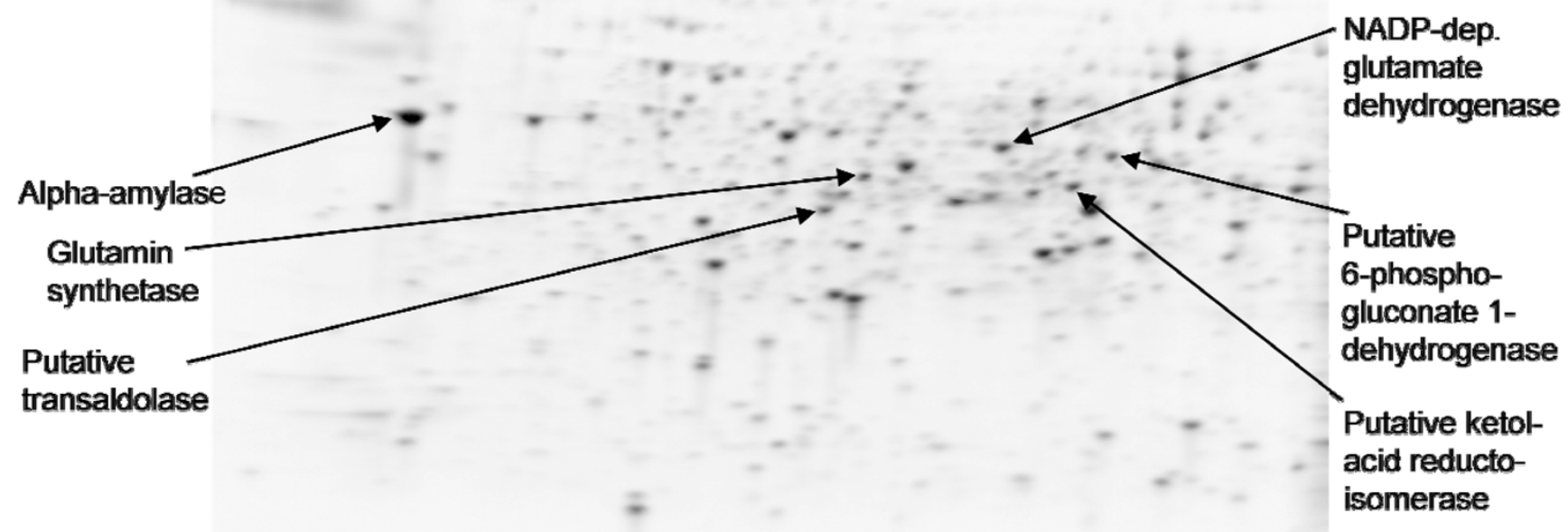

\section{C) $3 \%$ Lactate}

Beta-glucosidase

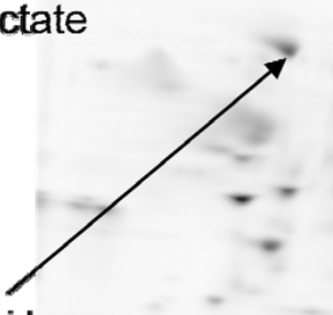

\section{Figure 4}

Example of representative 2D PAGE gels. 2D PAGE gels of proteins from A. niger IBT 28 I 44 after 60 hours growth on media containing $3 \%$ starch (top), $3 \%$ starch $+3 \%$ lactate (middle) and $3 \%$ lactate (bottom). 


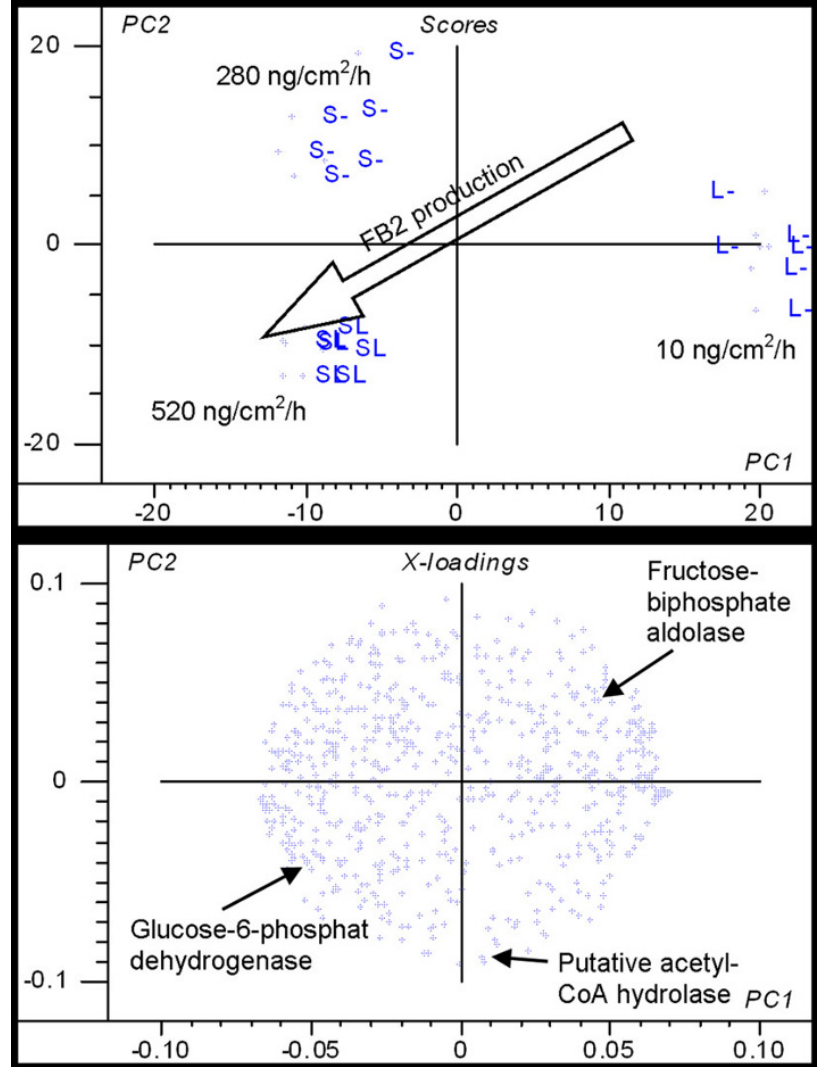

Figure 5

Illustration of variance in expressed proteins. Scoreplot (top) and loadingplot (bottom) from a principal component analysis of relative spot volume of all matched spots from the proteome analysis of $A$. niger. Shown is the $I^{\text {st }}$ and $2^{\text {nd }}$ principal component that explain $29 \%$ of the variance using validation with systematic exclusion of biological replicates.

the sequencing of the A. niger CBS 513.88 genome [22]. Per primo March 2009 the predicted proteome based on this sequencing project contained 13906 predicted proteins of which $47.1 \%$ had automatically assigned GO annotations and only 154 proteins had been assigned as manually reviewed in the UniProtKB database [39]. To circumvent the limited number of annotated proteins, we assigned annotations based on sequence similarity to characterised Swiss-Prot proteins in other species using BlastP [40]. A protein annotation was assigned to a protein if it had more than $80 \%$ sequence identity to a characterised Swiss-Prot protein and a "putative" annotation to proteins that had 50-80\% sequence identity to a characterised protein. Other proteins were assigned a "predicted" function if InterPro domains were predicted using InterProScan [41]. In this way, the identified proteins consisted of 6 ( 8 spots) fully characterised, 12 with annotation based on sequence similarity, 19 with putative annotation, 13 with predicted function and 6 ( 7 spots) uncharacterised proteins. The proteins with known functions were mainly involved in processes as: polysaccharide degradation; carbon-, nitrogen- and amino acid metabolism; energy production; protein synthesis, folding and degradation; redox balance and protection against oxidative stress. None of the characterised proteins were known to participate in secondary metabolite biosynthesis. A fatty acid synthase subunit alpha [UniProt: A2Q7B6] was identified, which was present at higher levels on SL compared to on $\mathrm{S}$ and $\mathrm{L}$ (cl. 35). This protein may contribute to fatty acid biosynthesis to be incorporated in the cell membrane; however it may also be an unrecognised polyketide synthase. One gene coding for a predicted aldo/keto reductase [UniProt: A2Q981] was located adjacent to the predicted $\mathrm{FB}_{2}$ biosynthesis cluster in the $A$. niger genome. But this protein was present at higher levels on starch-containing media (cl. 3) and therefore did not correlate with $\mathrm{FB}_{2}$ production. Furthermore, proteins involved in secondary metabolite synthesis or processes associated with transport or self-protection are not necessarily located within the clusters. One example is a reductase found to participate in aflatoxin biosynthesis in A. parasiticus, although it is not located within the aflatoxin cluster and was regulated differently than the aflatoxin cluster genes [42].

A throughout tendency was that many of the proteins influenced by the combination of starch and lactate in the medium were likely to affect either the acetyl-CoA level or the NADPH level as discussed below.

\section{Regulation of central metabolic enzymes}

The identified proteins appeared to include several important enzymes in the primary metabolism (Figure 6). Glucose 6-phosphate 1-dehydrogenase [Swiss-Prot: P48826] and a putative 6-phosphogluconate dehydrogenase [UniProt: Q874Q3], the first (rate-controlling) and third enzyme in the oxidative part of the pentose phosphate pathway (PPP) were present at higher levels on SL (cl. 35). They both reduce NADP to NADPH, and these enzymes are believed to be the main source of NADPH regeneration in the cell [43-46]. Additionally three enzymes in the nonoxidative part of the PPP were identified. A putative transketolase [UniProt: Q874Q5] and a putative transaldolase [UniProt: A2QMZ4] had tendencies for higher levels on SL (cl. 4). A predicted ribose/galactose isomerase [UniProt: $\mathrm{A} 2 \mathrm{QCB} 3]$, presumably with ribose 5-phosphate isomerase activity, was present at lower levels on SL (cl. 36). Lower level of this enzyme, responsible for synthesis of ribose 5phosphate required for the biosynthesis of some amino acids, nucleotides, and coenzymes, indicates that the PPP was optimised to NADPH regeneration rather than to 
Table 2: Clusters and interpretation

Description of clusters

No. of spots Total Identified

Tendency for higher levels on SL

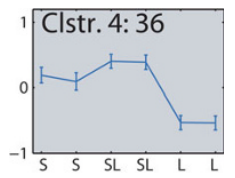

Lower levels on SL
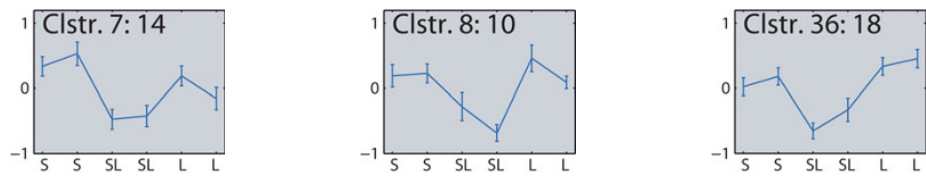

II

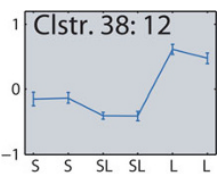

Tendency for lower levels on SL

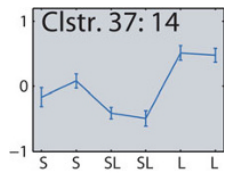

26

16

36

16

$45 \quad 3$

$52 \quad 0$

$21 \quad 4$

$\begin{array}{ll}58 & 3 \\ 308 & 1 \\ 649 & 58\end{array}$

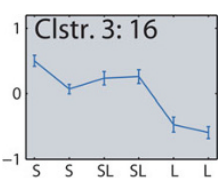

Lower levels if starch is present

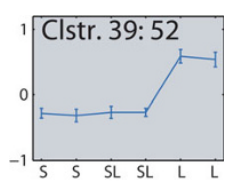

Higher levels if lactate is present

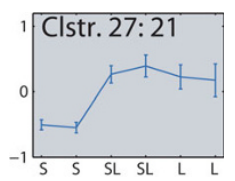

Lower levels if lactate is present
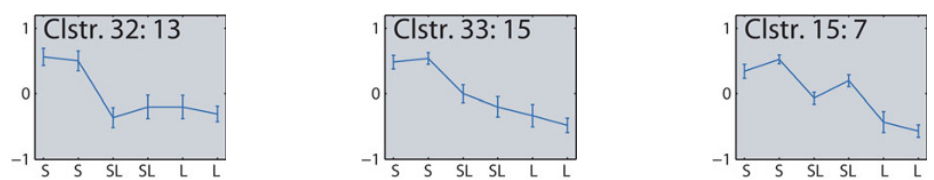

Clusters II, 16, 26, 30

Clusters I, 5, 6, 9, 10, 12, 13, 14, 17, 18, 19, 20, 21, 22, 23, 24, 25, 28, 29, 31, 34
Total
Possibly an effect, instability

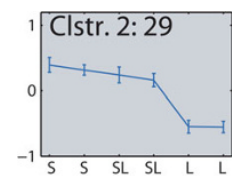

I) The graphs show the protein level profiles for selected clusters shown as transformed values between $-I$ and I, where 0 indicates the average protein level. The bars give the standard deviations within the clusters.

2) One spot, identified as glucoamylase [Swiss-Prot: P69328], was excluded from the data analysis (see text). Thus the total number of identified spots was 59.

nucleotide synthesis on SL. One glycolysis enzyme, fructose-biphosphate aldolase [UniProt: A2QDL0], had tendency for lower level on SL (cl. 37), which is in good agreement with a higher activity of the PPP. Those enzymes identified downstream of pyruvate, the entry point of lactate into metabolism, were either clearly present at higher levels on SL or had the tendency for higher level. This included a putative pyruvate 
Table 3: Identified proteins with higher levels on medium with starch + lactate

\begin{tabular}{|c|c|c|c|c|c|c|c|c|c|c|c|}
\hline \multirow{2}{*}{$\frac{\text { Protein }}{\text { Annotation }^{2}}$} & \multicolumn{2}{|l|}{ Spot } & \multicolumn{7}{|c|}{ Identification' } & \multicolumn{2}{|c|}{ Expression } \\
\hline & Id. & Mass $\mathrm{kDa}^{3}$ & Database & Acc. no. & Mass kDa & pl & MP & Score & SC \% & Cl. no. & Profile \\
\hline $\begin{array}{l}\text { Alpha-amylase, } \\
\text { extracellular }\end{array}$ & 6601 & 53 & NCBInr & A2QL05 & $55^{6}$ & 4.5 & 5 & 315 & 13 & 35 & \\
\hline $\begin{array}{l}\text { Fatty acid synthase } \\
\text { subunit alpha }\end{array}$ & 6465 & $76^{4}$ & NCBInr & A2Q7B6 & 205 & 5.9 & 10 & 387 & 5 & 35 & \\
\hline $\begin{array}{l}\text { Glucose-6-phosphate } \\
\text { I-dehydrogenase }\end{array}$ & 6561 & 59 & Swiss-Prot & P48826 & 59 & 6.2 & 3 & 130 & 7 & 35 & \\
\hline Glutamine synthetase & 6714 & 42 & NCBInr & A2Q9R3 & 42 & 5.5 & 4 & 290 & 16 & 4 & \\
\hline $\begin{array}{l}\text { Heat shock protein } \\
\text { Hsp70 }\end{array}$ & 6481 & 73 & NCBInr & A2QPM8 & 70 & 5.1 & 5 & 198 & 12 & 4 & \\
\hline $\begin{array}{l}\text { Isocitrate } \\
\text { dehydrogenase } \\
\text { [NADP], } \\
\text { mitochondrial, } \\
\text { precursor }\end{array}$ & 6644 & 48 & Swiss-Prot & P79089 & 56 & 8.5 & 8 & 339 & 14 & 19 & \\
\hline $\begin{array}{l}\text { NADP-dependent } \\
\text { glutamate } \\
\text { dehydrogenase }\end{array}$ & 6647 & 48 & NCBInr & A2QHT6 & 50 & 5.8 & 6 & 382 & 18 & 4 & \\
\hline $\begin{array}{l}\text { Predicted 2- } \\
\text { nitropropane } \\
\text { dioxygenase }\end{array}$ & 6737 & 41 & NCBInr & $\mathrm{A} 2 \mathrm{QK} \times 9$ & $38^{6}$ & 5.7 & 4 & 112 & 17 & 35 & \\
\hline $\begin{array}{l}\text { Predicted glucose- } \\
\text { methanol-choline } \\
\text { (Gmc) oxidoreductase }\end{array}$ & 6515 & 65 & NCBInr & A2R50I & 65 & 5.4 & 6 & 373 & 18 & 35 & \\
\hline $\begin{array}{l}\text { Predicted } \\
\text { methyltransferase }\end{array}$ & 6810 & 36 & NCBInr & A2QNF3 & 37 & 5.9 & 5 & 200 & 21 & 30 & \\
\hline $\begin{array}{l}\text { Predicted NADH } \\
\text { cytochrome b5 } \\
\text { reductase }\end{array}$ & 6693 & 44 & NCBInr & $A 2 R 2 Z 2$ & 46 & 5.4 & 6 & 530 & 20 & 4 & \\
\hline $\begin{array}{l}\text { Predicted ubiquitin } \\
\text { conjugating enzyme }\end{array}$ & 7044 & 17 & NCBInr & A2QDZ9 & 17 & 5.5 & 2 & 105 & 18 & 4 & \\
\hline $\begin{array}{l}\text { Putative 6- } \\
\text { phosphogluconate } \\
\text { dehydrogenase, } \\
\text { decarboxylating }\end{array}$ & 6660 & 47 & NCBInr & Q874Q3 & 55 & 5.9 & 9 & 527 & 27 & 35 & \\
\hline $\begin{array}{l}\text { Putative aconitate } \\
\text { hydratase, } \\
\text { mitochondrial }\end{array}$ & 6472 & 75 & NCBInr & A2QSF4 & 84 & 6.2 & 7 & 278 & 11 & 35 & \\
\hline $\begin{array}{l}\text { Putative heat shock } \\
\text { protein Sscl, } \\
\text { mitochondrial }\end{array}$ & 6487 & 7I & NCBInr & $\mathrm{A} 2 \mathrm{R} 7 \times 5$ & 72 & 5.6 & 5 & 282 & 9 & 4 & \\
\hline $\begin{array}{l}\text { Putative histidine } \\
\text { biosynthesis } \\
\text { trifunctional protein }\end{array}$ & 6413 & $101^{5}$ & NCBInr & A2QAS4 & 92 & 5.4 & 2 & 147 & 3 & 4 & \\
\hline $\begin{array}{l}\text { Putative inositol-I- } \\
\text { phosphate synthase }\end{array}$ & 6573 & 57 & NCBInr & A2QV05 & 58 & 5.7 & 2 & 62 & 4 & 35 & \\
\hline $\begin{array}{l}\text { Putative ketol-acid } \\
\text { reductoisomerase, } \\
\text { mitochondrial }\end{array}$ & 6730 & 41 & NCBInr & A2QU08 & $45^{6}$ & 8.9 & 8 & 467 & 17 & 35 & \\
\hline $\begin{array}{l}\text { Putative oxoglutarate } \\
\text { dehydrogenase }\end{array}$ & 6408 & $101^{5}$ & NCBInr & A2QIU5 & 119 & 6.3 & 10 & 349 & 8 & 35 & \\
\hline $\begin{array}{l}\text { Putative peroxiredoxin } \\
\text { pmp20, peroxisomal } \\
\text { membrane }\end{array}$ & 7000 & 22 & NCBInr & A2R0G9 & 19 & 5.4 & 8 & 610 & 54 & 4 & \\
\hline $\begin{array}{l}\text { Putative peroxiredoxin } \\
\text { Prxl, mitochondrial }\end{array}$ & 6944 & 28 & NCBInr & A2QIF8 & 23 & 5.2 & 5 & 224 & 22 & 4 & \\
\hline $\begin{array}{l}\text { Putative pyruvate } \\
\text { dehydrogenase EI } \\
\text { component subunit } \\
\text { alpha, mitochondrial } \\
\text { precurser }\end{array}$ & 7028 & $18^{4}$ & NCBInr & A2QPII & 45 & 7.6 & 2 & 160 & 7 & 30 & \\
\hline Putative transaldolase & 6787 & 38 & NCBInr & A2QMZ4 & 36 & 5.6 & 5 & 319 & 20 & 4 & \\
\hline
\end{tabular}


Table 3: Identified proteins with higher levels on medium with starch + lactate (Continued)

\begin{tabular}{|c|c|c|c|c|c|c|c|c|c|c|c|}
\hline Putative transketolase & 6471 & 75 & NCBInr & Q874Q5 & 75 & 6.0 & 6 & 246 & 11 & 4 & $\Gamma$ \\
\hline Thioredoxin reductase & 6680 & 45 & NCBInr & A2Q9P0 & 39 & 5.2 & 6 & 449 & 22 & 4 & \\
\hline $\begin{array}{l}\text { Uncharacterised } \\
\text { protein }\end{array}$ & 6965 & 26 & NCBInr & A2QDUI & 19 & 5.4 & 3 & 147 & 15 & 4 & \\
\hline $\begin{array}{l}\text { Uncharacterised } \\
\text { protein }\end{array}$ & 6591 & 55 & NCBInr & A2QDX8 & 57 & 5.8 & 10 & 601 & 23 & 4 & \\
\hline $\begin{array}{l}\text { Uncharacterised } \\
\text { protein }\end{array}$ & 6592 & 55 & NCBInr & A2QDX8 & 57 & 5.8 & 10 & 717 & 25 & 4 & \\
\hline $\begin{array}{l}\text { Uncharacterised } \\
\text { protein }\end{array}$ & 7059 & 16 & NCBInr & A5ABN7 & 26 & 10.3 & 2 & 145 & 14 & 35 & \\
\hline $\begin{array}{l}\text { Uncharacterised } \\
\text { protein }\end{array}$ & 7092 & $13^{5}$ & NCBInr & A2QSA8 & 13 & 5.2 & 2 & 249 & 35 & 4 & \\
\hline
\end{tabular}

List of identified proteins showing from left to right: Protein name, spot id and observed mass on gels, database, UniProt KB accession number, expected mass and isoelectric point ( $\mathrm{pl}$ ), number of matching peptide sequences (MP), Mowse Score (Score) and sequence coverage (SC), cluster and graph showing protein levels (average relative spot volume \pm standard deviation) on media containing $3 \%$ starch (left/blue), $3 \%$ starch $+3 \%$ lactate (middle/purple) and 3\% lactate (right/red).

I) Identification was based on Mascot MS/MS Ion Search using sequence data from the databases Swiss-Prot or NCBInr. Protein matches with significant $(p<0.05)$ Mowse Scores and $\geq 2$ matching peptides were regarded as possible candidates for identification.

2) Annotation of uncharacterised proteins was based on sequence homology to characterised Swiss-Prot proteins using BlastP. Proteins were given a full annotation if they had $>80 \%$ sequence identity to a characterised Swiss-Prot protein or a putative annotation if they had $50-80 \%$ sequence identity to a characterised protein. Remaining proteins were assigned a "predicted" function if InterPro domains were predicted using InterProScan.

3) Observed mass on reference gel calibrated with molecular weight standards (I4.4-97.4 kDa).

4) The spot is most likely a fragment as the retrieved peptides were localized in one of the ends of the protein sequence.

5) Mass above or below calibration range.

6) The protein is predicted to contain a signal peptide.

7) The protein is predicted to be glycosylated.

dehydrogenase (E1 subunit alpha) [UniProt: A2QPI1] (cl. 30) and the three enzymes in the tricarboxylic acid (TCA) cycle converting citrate to isocitrate, the irreversible step from isocitrate to 2-oxoglutarate, and from 2-oxoglutarate to succinyl-CoA. The first and the third TCA cycle enzyme, a putative aconitate hydratase [UniProt: A2QSF4] and a putative 2-oxoglutarate dehydrogenase [UniProt: A2QIU5], was clearly present at higher levels on SL (cl. 35), while NADP-dependant isocitrate dehydrogenase [Swiss-Prot: P79089] had a tendency for higher level but with a noisy profile (cl. 19). One enzyme that occurred at higher level when lactate was present in the media (cl. 27) was a putative acetyl-CoA hydrolase [UniProt: A2R8G9]. This enzyme has been designated to catalyse the hydrolysis of acetyl-CoA to acetate, but may rather posses CoA transferase activity between succinyl-, propionyl- and acetyl-CoA and the corresponding acids [47]. In yeast, acetyl-CoA hydrolase is involved in trafficking of acetyl-CoA across membranes in the form of acetate and thus is expected to be important for regulation of the acetyl-CoA level $[48,49]$.

To summarize, higher levels of the enzymes in the PPP that generate NADPH during growth on SL compared to on $\mathrm{S}$ and $\mathrm{L}$ indicate an increased ability to regenerate NADPH when the NADP:NADPH ratio is increased. The higher levels of the enzymes in the metabolism of pyruvate after pyruvate enters mitochondria on SL and the higher levels of putative acetyl-CoA hydrolase in presence of lactate indicate an increased amount of carbon passing through acetyl-CoA during growth on SL.

\section{Regulation of enzymes influencing the NADPH level}

A remarkable requirement for NADPH on SL medium is pointed out by the simultaneous effect on several of the relatively few enzymes that contribute to NADPH regeneration. We found glucose 6-phosphate dehydrogenase, putative 6-phosphogluconate dehydrogenase, NADP-dependent isocitrate dehydrogenase and putative ketol-acid reductoisomerase [UniProt: A2QUO8], an enzyme in isoleucine, leucine and valine biosynthesis, to be present at higher levels on SL. Regulation of these enzymes is probably due to an increased NADP:NADPH ratio. The activity of the first enzyme, glucose 6phosphate dehydrogenase, is known to be regulated by NADP:NADPH levels [50]. Larochelle et al. [51] showed in yeast that transcription of the corresponding gene was also affected by the NADPH level and they attributed this to a transcription factor Stb5. The yeast cell regulates the metabolism to counteract a high NADP:NADPH ratio by up-regulating the PPP and down-regulating glycolysis [51], which neatly corresponds to the changes we have observed in these pathways.

A. niger needs a supply of NADPH for several anabolic and biosynthetic processes as well as for protection 
Table 4: Identified proteins with lower levels on medium with starch + lactate

\begin{tabular}{|c|c|c|c|c|c|c|c|c|c|c|c|}
\hline \multirow{2}{*}{$\frac{\text { Protein }}{\text { Annotation }^{2}}$} & \multicolumn{2}{|l|}{ Spot } & \multicolumn{7}{|c|}{ Identification' } & \multicolumn{2}{|c|}{ Expression } \\
\hline & Id. & Mass $\mathbf{k D a}^{3}$ & Database & Acc. no. & Mass kDa & pl & MP & Score & SC $\%$ & Cl. no. & Profile \\
\hline Aldehyde dehydrogenase & 6605 & 53 & Swis-Prot & P4I75I & 54 & 6.0 & 10 & 908 & 34 & 37 & \\
\hline Aldehyde dehydrogenase & 6615 & 52 & Swis-Prot & P4I75I & 54 & 6.0 & 7 & 646 & 20 & 38 & \\
\hline $\begin{array}{l}\text { Beta-glucosidase I } \\
\text { precurser }\end{array}$ & 6360 & $130^{5}$ & NCBInr & Q30BH9 & 94 & 4.7 & 5 & 267 & 6 & 36 & \\
\hline $\begin{array}{l}\text { Fructose-biphosphate } \\
\text { aldolase }\end{array}$ & 6766 & 39 & NCBInr & A2QDL0 & 40 & 5.5 & 8 & 697 & 28 & 37 & \\
\hline $\begin{array}{l}\text { Predicted estherase/lipase/ } \\
\text { thioesterase }\end{array}$ & 6451 & 82 & NCBInr & A2QTP5 & 84 & 5.4 & 9 & 543 & 18 & 37 & \\
\hline $\begin{array}{l}\text { Predicted fumaryl- } \\
\text { acetoacetate hydrolase }\end{array}$ & 6663 & 47 & NCBInr & A2QIN6 & 45 & 5.2 & 6 & 611 & 24 & 38 & \\
\hline $\begin{array}{l}\text { Predicted glutathione-S- } \\
\text { transferase }\end{array}$ & 6952 & 27 & NCBInr & A2R874 & 24 & 5.1 & 5 & 391 & 31 & 37 & \\
\hline $\begin{array}{l}\text { Predicted NAD-dependant } \\
\text { epimerase/dehydratase }\end{array}$ & 6707 & 43 & NCBInr & A2R992 & 38 & 5.7 & 7 & 397 & 26 & 38 & \\
\hline $\begin{array}{l}\text { Predicted ribose/galactose } \\
\text { isomerase }\end{array}$ & 7035 & 18 & NCBInr & A2QCB3 & 17 & 7.7 & 7 & 593 & 61 & 36 & \\
\hline $\begin{array}{l}\text { Predicted Zn-containing } \\
\text { alcohol dehydrogenase }\end{array}$ & 6718 & 42 & NCBInr & A2QAN5 & 39 & 5.8 & 4 & 298 & 19 & 38 & \\
\hline $\begin{array}{l}\text { Putative I- } \\
\text { aminocyclopropane-I- } \\
\text { carboxylate deaminase }\end{array}$ & 6715 & 42 & $\begin{array}{l}\text { NCBInr } \\
\text { Cross sp. }\end{array}$ & Q7S3B7 & 39 & 5.8 & 2 & 115 & 11 & 38 & \\
\hline $\begin{array}{l}\text { Putative glutamate } \\
\text { carboxypeptidase-like }\end{array}$ & 6609 & 53 & NCBInr & A2QY36 & 53 & 5.2 & 12 & 811 & 29 & 38 & \\
\hline $\begin{array}{l}\text { Putative HIT family } \\
\text { protein I }\end{array}$ & 7091 & $13^{5}$ & NCBInr & A2QLN7 & 15 & 6.3 & 3 & 227 & 40 & 37 & \\
\hline $\begin{array}{l}\text { Putative } \mathrm{H} \text {-transporting two } \\
\text { sec tor ATPase subunit F, } \\
\text { vacuolar }\end{array}$ & 7083 & 14 & NCBInr & A2QCE6 & 14 & 5.3 & 4 & 340 & 44 & 37 & \\
\hline $\begin{array}{l}\text { Putative NADH ubiquinone } \\
\text { reductase, } 40 \mathrm{kDa} \text { subunit, } \\
\text { mitochondrial }\end{array}$ & 6738 & 41 & NCBInr & $\mathrm{A} 2 \mathrm{QSH} 0$ & 43 & 6.7 & 5 & 307 & 17 & 38 & \\
\hline $\begin{array}{l}\text { Putative peroxiredoxin } \\
\text { pmp } 20 \text {, peroxisomal } \\
\text { membrane }\end{array}$ & 7031 & 18 & NCBInr & A2R6R3 & 18 & 5.6 & 5 & 431 & 37 & 38 & \\
\hline $\begin{array}{l}\text { Superoxide dismutase } \\
\text { Cu-Zn, cytoplasmic }\end{array}$ & 7046 & 17 & Swiss-Prot & A2QMY6 & 16 & 5.9 & 5 & 323 & 38 & 36 & \\
\hline Ubiquitin-like protein & 7113 & $11^{5}$ & NCBInr & A2QKNI & 9 & 5.8 & 5 & 272 & 60 & 37 & \\
\hline Uncharacterised protein & 7002 & 21 & NCBInr & $\mathrm{A} 2 \mathrm{QLX} 7$ & 20 & 6.1 & 7 & 592 & 55 & 8 & \\
\hline Uncharacterised protein & 7074 & $15^{4}$ & NCBInr & A2QBG0 & 34 & 5.1 & 6 & 609 & 24 & 38 & \\
\hline
\end{tabular}

See legend and notes to table 3 .

Table 5: Identified proteins with levels influenced by presence of starch

\begin{tabular}{|c|c|c|c|c|c|c|c|c|c|c|c|}
\hline \multirow{2}{*}{$\frac{\text { Protein }}{\text { Annotation }^{2}}$} & \multicolumn{2}{|l|}{ Spot } & \multicolumn{7}{|c|}{ Identification' } & \multicolumn{2}{|c|}{ Expression } \\
\hline & Id. & Mass $\mathrm{kDa}^{3}$ & Database & Acc. no. & Mass kDa & pl & MP & Score & SC $\%$ & Cl. no. & Profile \\
\hline Alpha-glucosidase, extracellular & 6354 & $|5|^{5}$ & Swiss-Prot & P56526 & 109 & 5.1 & 7 & 497 & 10 & 2 & \\
\hline Glucoamylase isoform GI, glycosylated & 6000 & $130^{5}$ & Swiss-Prot & P69328 & $69^{6,7}$ & 4.3 & 5 & 308 & 10 & - & \\
\hline Predicted aldo/keto reductase & 6781 & 38 & NCBInr & A2Q98I & 37 & 6.0 & 5 & 335 & 17 & 3 & \\
\hline Pyruvate decarboxylase & 6540 & 61 & NCBInr & A5AA75 & 63 & 6.3 & 6 & 412 & 15 & 3 & \\
\hline Translation elongation factor 2 & 6836 & $35^{4}$ & NCBInr & A2QD36 & 94 & 6.5 & 6 & 556 & 7 & 11 & \\
\hline
\end{tabular}

See legend and notes to table 3 . 
Table 6: Identified proteins with levels influenced by presence of lactate

\begin{tabular}{|c|c|c|c|c|c|c|c|c|c|c|c|}
\hline \multirow{2}{*}{$\frac{\text { Protein }}{\text { Annotation }^{2}}$} & \multicolumn{2}{|l|}{ Spot } & \multicolumn{7}{|c|}{ Identification' } & \multicolumn{2}{|c|}{ Expression } \\
\hline & Id. & Mass $\mathrm{kDa}^{3}$ & Database & Acc. no. & Mass kDa & pl & MP & Score & SC $\%$ & Cl. no. & Profile \\
\hline $\begin{array}{l}\text { Alpha-glucfosidase, } \\
\text { extracellular }\end{array}$ & 6355 & $157^{5}$ & Swiss-Prot & P56526 & 109 & 5.1 & 3 & 147 & 4 & 27 & \\
\hline Predicted NMR-like protein & 6783 & 38 & NCBInr & $\mathrm{A} 2 \mathrm{R} 745$ & $34^{6}$ & 5.2 & 3 & 225 & 14 & 27 & \\
\hline $\begin{array}{l}\text { Putative acetyl-CoA } \\
\text { hydrolase, glycosylated }\end{array}$ & 6533 & 62 & NCBInr & A2R8G9 & $58^{7}$ & 6.0 & 5 & 253 & 10 & 27 & \\
\hline $\begin{array}{l}\text { Putative NADH ubiquinone } \\
\text { reductase, } 31 \mathrm{kD} \text { subunit }\end{array}$ & 6888 & 32 & NCBInr & A2QWSI & 32 & 7.7 & 2 & 104 & 8 & 27 & \\
\hline
\end{tabular}

See legend and notes to table 3 .

against oxidative stress. A supply of NADPH is for example required in order to utilize nitrate as nitrogen source, since the enzyme that converts nitrate to nitrite, nitrate reductase, uses NADPH as cofactor [44].

On SL, we observed higher levels of enzymes involved in fatty acid biosynthesis, ammonium assimilation and protection against oxidative stress, those activities may increase the NADP:NADPH ratio [52]. As mentioned previously, we observed a higher level of a fatty acid synthase subunit alpha on SL (cl. 35) that requires NADPH in order to catalyse the biosynthesis of fatty acids. We also identified NADP-dependant glutamate dehydrogenase [UniProt: A2QHT6] involved in ammonium assimilation and thioredoxin reductase [UniProt: A2Q9P0] that utilises NADPH to reduce thioredoxin during conditions with oxidative stress; both had tendencies for higher levels on SL (cl. 4). Furthermore, the polyketide synthase involved in $\mathrm{FB}_{2}$ biosynthesis uses NADPH as cofactor [13] and that may also affect the NADP:NADPH ratio.

These results show a clear tendency towards increased NADPH turnover and regeneration during growth on SL.

\section{Relation between regulated proteins and $\mathrm{FB}_{\mathbf{2}}$ biosynthesis} The identified proteins regulated on SL were mainly enzymes in the primary metabolism and other processes that likely affect the intracellular levels of acetyl-CoA or $\mathrm{NADPH}$. The higher $\mathrm{FB}_{2}$ production on SL is thus most likely a result of changes in the metabolism due to lactate degradation. Acetyl-CoA is a precursor for production of $\mathrm{FB}_{2}$ as well as for other polyketide-derived metabolites [13]. High level of acetyl-CoA during growth on SL may thus be what drives the high $\mathrm{FB}_{2}$ production. This is supported by the observation that pyruvate had a similar effect as lactate on $\mathrm{FB}_{2}$ production. A good ability to regenerate NADPH when the NADP:NADPH ratio is increased may be an important prerequisite for the high $\mathrm{FB}_{2}$ production on SL.
However, the effect of added lactate to a medium containing starch on $\mathrm{FB}_{2}$ production was dramatic and not expected to be solely precursor-driven. Further, the 12 secondary metabolites measured in this study, which include polyketides, non-ribosomal peptides and polyketide-derived alkaloids, were affected differently by the presence of starch and lactate and a pattern reflecting the biosynthetic origin of the metabolites was not evident. This supports that the influence of lactate in combination with starch on $\mathrm{FB}_{2}$ production is regulatory rather than an effect solely driven by abundance of precursors. We hypothesise that the $\mathrm{FB}_{2}$ production, when induced, could be regulated globally according to the nutrient/ energy state. As a central compound in metabolism, carefully regulated and compartmentalised, acetyl-CoA may be a candidate for this [53]. Acetyl-CoA has been shown to be able to affect transcription in vitro [54]. In yeast, it has been suggested that transcription of the inositol 1-phosphate synthase gene, ino1, is influenced by the acetyl-CoA level during conditions with high levels of energy-rich metabolites [55]. In accordance, we identified a putative inositol-1-phosphate synthase [UniProt: A2QV05] among the proteins with higher levels on SL medium (cl. 35). Inositol-1-phosphate synthase is the first and rate-controlling enzyme in the inositol biosynthesis pathway and converts glucose 6phosphate into inositol 1-phosphate. Inositol is incorporated into phosphatidylinositol that in turn is a precursor of sphingolipids and inositol polyphosphates, required for a diverse set of processes that include glycolipid anchoring of proteins, signal transduction (regulation of chromatin remodeling and transcription), mRNAexport and vesicle trafficking [56,57]. Acetyl-CoA is also a substrate for protein acetylation by protein acetylases, and acetylation can influence both gene expression and protein activity [58]. In A. parasiticus there has been observed a correlation between initiation and spread of histone acetylation in the aflatoxin gene promoters and the initiation of aflatoxin gene expression [59]. Another study of $A$. nidulans has shown that genetic deletion of a histone deacetylase caused elevated gene 


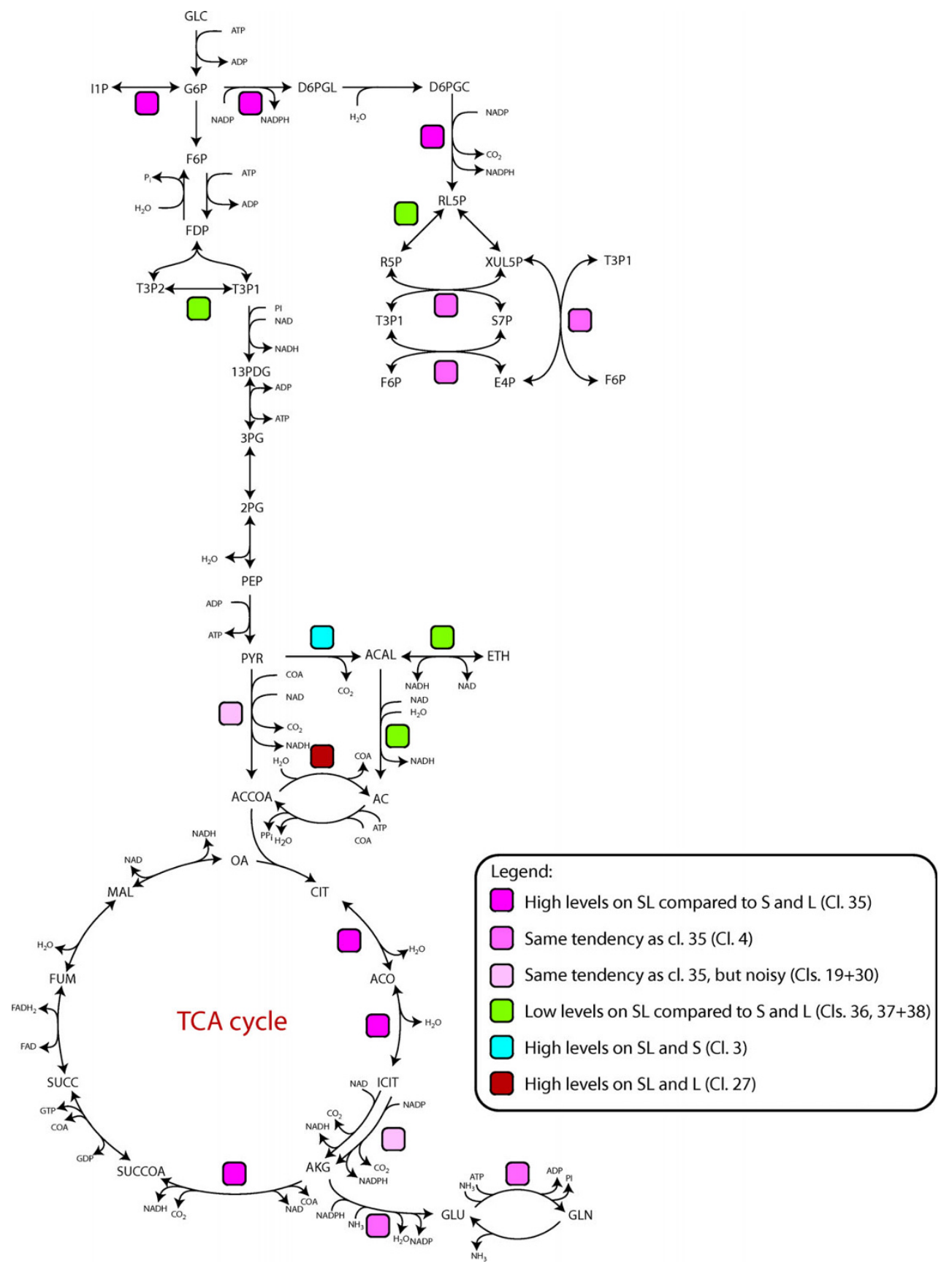

Figure 6

Identified proteins within the primary metabolism. Pathway map showing an outline of the glycolysis, the pentose phosphate pathway, pyruvate metabolism, the tricarboxylic acid cycle and ammonium assimilation enzymes with the identified proteins indicated. Modified from map of A. niger metabolism published by Andersen et al [68]. I3PDG: I,3-bisphospho-Dglycerate, 2PG: 2-phospho-D-glycerate, 3PG: 3-phospho-D-glycerate, AC: acetate, ACAL: acetaldehyde, ACCOA: acetyl coenzyme A, ACO: cis-aconitate, AKG: 2-oxoglutarate, CIT: citrate, D6PGC: 6-phospho-D-gluconate, D6PGL: d-glucono-I,5lactone 6-phosphate, E4P: D-erythrose 4-phosphate, ETH: ethanol, F6P: beta-D-fructose 6-phosphate, FDP: beta-D-fructose I,6-bisphosphate, FUM: fumarate, G6P: alpha-D-glucose 6-phosphate, GLC: alpha-D-glucose, GLN:L-glutamine, GLU: Lglutamate, IIP:ID-inositol 3-phosphate, ICIT: isocitrate, MAL: (S)-malate, OA: oxaloacetate, PEP: phosphoenolpyruvate, PYR: pyruvate, R5P: D-ribose 5-phosphate, RL5P: D-ribulose 5-phosphate, S7P: sedoheptulose 7-phosphate, SUCC: succinate, SUCCoA: succinyl coenzyme A, T3PI: D-glyceraldehyde 3-phosphate, T3P2: glycerone phosphate (DHAP), XUL5P:D-xylulose 5-phosphate. 
expression and enhanced production of sterigmatocystin and penicillin [60]. The same study demonstrated that treatment with histone deacetylase inhibitors could enhance production of some secondary metabolites by Penicillium expansum and Alternaria alternata, indicating that histone acetylation and deacetylation have a role in regulation of secondary metabolite production in a broad range of fungal genera.

Secondary metabolite synthesis can be subject to multiple regulatory mechanisms. Regulation of fumonisin $B_{1}$ biosynthesis in $F$. verticillioides has been found to be complex with several positive and negative regulators and influenced by nitrogen, carbon and $\mathrm{pH}[12,61]$. Corresponding to our results, fumonisin $\mathrm{B}_{1}$ production in $F$. verticillioides has been shown to be induced by the presence of starch [62]. However, F. verticillioides and A. niger are widely different physiologically and genetically, thus production and regulation of fumonisin biosynthesis are not expected to be identical [6].

During conditions where A. niger spends resources on producing extracellular enzymes for degradation of plant tissue and starch, protection against other microorganisms competing for nutrients would be beneficial. Fumonisin $\mathrm{B}_{1}$ has been shown to have antifungal activity against species as Alternaria alternata, Penicillium expansum, Botrytis cinerea and Fusarium graminearum [63], thus $\mathrm{FB}_{2}$ could be expected to have a similar effect. Increased production of $\mathrm{FB}_{2}$ during conditions with high acetylCoA level may thus have evolved because antifungal activity was advantageous to A. niger as a way to protect the nutrient sources in the environment.

\section{Conclusions}

Our results show that lactate, when supplemented in a rich substrate containing nitrate and starch, can increase the $\mathrm{FB}_{2}$ production in $A$. niger. Based on the identified proteins within the central metabolism, we suggest this to be due to changes in the balance of intracellular metabolites towards a higher level of carbon passing through acetyl-CoA and a high capacity to regenerate NADPH. Given that the $\mathrm{FB}_{2}$ biosynthesis genes are induced, the results indicate that the availability of precursors and NADPH has a large influence on production of $\mathrm{FB}_{2}$. The production of certain other secondary metabolites was affected in a similar fashion as $\mathrm{FB}_{2}$ by lactate (fumonisin $\mathrm{B}_{4}$, orlandin, desmethylkotanin and pyranonigrin A), while other secondary metabolites were not (ochratoxin $\mathrm{A}$, ochratoxin alpha, malformin A, malformin $\mathrm{C}$, kotanin, aurasperone $\mathrm{B}$, tensidol B). Consequently, as these metabolites were affected differently by the presence of starch and lactate, they must be regulated differently in A. niger.
We find it likely that the influence of starch and lactate/ pyruvate on $\mathrm{FB}_{2}$ production is part of a global regulation inferred by the nutrient/energy state and propose that this could be through the action of acetyl-CoA. Whether, if and how, acetyl-CoA affects gene transcription or activity of enzymes in the $\mathrm{FB}_{2}$ biosynthesis pathway could be the scope of relevant, future studies.

It remains to be seen whether production of secondary metabolites in other species of filamentous fungi is increased by presence of starch and lactate. The effect of starch and lactate in combination may be relevant to be aware of for starch-containing foods and feeds where fungi occur concurrently with lactic acid fermentation, which could be the case in low-fat mould-fermented sausages, in fermented vegetable products and in silage. Technologically, the obtained knowledge of substrate influence on production of specific secondary metabolites could be beneficial, as lactate or other carbon sources could be used to increase metabolite production during industrial fermentation.

\section{Methods \\ Strain}

A. niger IBT 28144 (CBS 101705) was obtained from the IBT culture collection and maintained on silica gel. The culture was used after two successive inoculations on Czapek Yeast Autolysate agar (CYA), incubated 7 days in dark at $25^{\circ} \mathrm{C}$.

\section{Media}

Media were modified from CYA and contained per L: $5 \mathrm{~g}$ Yeast extract (Biokar Diagnostics, Beauvais, France); $3 \mathrm{~g}$ $\mathrm{NaNO}_{3} ; 1 \mathrm{~g} \mathrm{~K} \mathrm{HPO}_{4} ; 0,5 \mathrm{~g} \mathrm{KCl} ; 0,5 \mathrm{~g} \mathrm{MgSO}_{4} \cdot 7 \mathrm{H}_{2} \mathrm{O}$; $0,01 \mathrm{~g} \mathrm{FeSO}_{4} \cdot 7 \mathrm{H}_{2} \mathrm{O} ; 0,01 \mathrm{~g} \mathrm{ZnSO}_{4} \cdot 7 \mathrm{H}_{2} \mathrm{O} ; 0,005 \mathrm{~g}$ $\mathrm{CuSO}_{4} \cdot 5 \mathrm{H}_{2} \mathrm{O}$ and $20 \mathrm{~g}$ agar (Sobigel, VWR - Bie \& Berntsen A/S, Herlev, Denmark). Soluble potato starch, $60 \%$ potassium L-lactate solution, maltose monohydrate, D-xylose and/or sodium pyruvate (all Sigma Aldrich, St. Louis, Missouri, USA) were added according to the indicated percentages in $\mathrm{w} / \mathrm{v}$. Lactate, maltose, xylose and pyruvate and the remaining ingredients were sterilised separately, at $121^{\circ} \mathrm{C}$ for 15 min., cooled to $60^{\circ}$ Cbefore the ingredients were mixed, adjusted to $\mathrm{pH} 5.5$ with sterile filtered $2 \mathrm{M} \mathrm{KOH}$ or $5 \mathrm{M} \mathrm{HCl}$ and poured into petri dishes.

\section{Inoculation and incubation}

Conidium suspensions were prepared in spore suspension media ( $0.50 \mathrm{~g}$ Tween $80,0.50 \mathrm{~g}$ agar to $1 \mathrm{~L}$ water), filtrated through Miracloth (Merck KGaA, Darmstadt, Germany) to remove mycelium fragments and adjusted to $10^{6}$ conidia/ml. Each agar plate was surface inoculated 
with $10^{5}$ conidia using a drigalsky spatula. Incubation was in dark at $25^{\circ} \mathrm{C}$.

\section{Determination of growth}

Biomass production was determined in triplicate for surface inoculated cultures on agar plates covered with a $0.45 \mu \mathrm{m}$ polycarbonate membrane (Isopore ${ }^{\mathrm{TM}}$, Millipore, Billerica, Massachusetts, USA). The whole mycelium was collected and the dry weight was determined after drying at $100^{\circ} \mathrm{C}$ for $20-24 \mathrm{~h}$.

\section{Determination of conidium production}

Eight agar plugs (4 $\mathrm{mm}$ in diameter) were dispensed in $4 \mathrm{ml}$ peptone water (1 g peptone (Difco, BD, Franklin Lakes, New Jersey, USA) to $1 \mathrm{l}$ destilled water) and replicate measures of the conidium concentration were determined in a Thoma counting chamber for triplicate cultures.

\section{Extraction of secondary metabolites}

The method described by Smedsgaard [29] with some modifications was used for secondary metabolite extraction. A sample of 8 agar plugs ( $4 \mathrm{~mm}$ in diameter) taken randomly from the plate was extracted with $1 \mathrm{ml}$ methanol/dichloromethane/ethyl acetate (v/v/v 1:2:3) containing $1 \%(\mathrm{v} / \mathrm{v})$ formic acid for 60 min using ultrasonication. The extract was transferred to a new vial and the solvent evaporated. The agar plug sample was re-

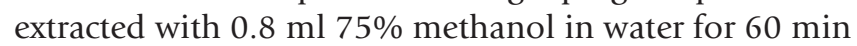
using ultrasonication and the extract combined with the dry extract of first extraction. The residues were redissolved by whirley mixing followed by $10 \mathrm{~min}$ ultrasonication and the extracts were filtrated through $0.45 \mu \mathrm{m}$ PTFE filters.

\section{LC-MS and HPLC-FLD for determination of secondary metabolites}

LC-MS was performed on an Agilent 1100 LC system (Agilent Technologies, Santa Clara, California, USA) with a $40^{\circ} \mathrm{C}, 50 \mathrm{~mm} \times 2 \mathrm{~mm}$ i. d., $3 \mu \mathrm{m}$, Luna C18 II column (Phenomenex, Torrance, California, USA). The LC system was coupled to a single quadropole mass detector (LC/MSD VL, Agilent technologies) with an atmospheric pressure ionisation source and to a 200$700 \mathrm{~nm}$ diode array detector. A sample volume of $3 \mu \mathrm{l}$ was injected and eluted at a flow rate of $0.3 \mathrm{ml} / \mathrm{min}$ using a water-acetonitrile gradient system starting from $15 \%$ acetonitrile that was increased linearly to $100 \%$ in $20 \mathrm{~min}$ and with a holding time of $2 \mathrm{~min}$. Water and acetonitrile were buffered with $20 \mathrm{mM}$ formic acid and $5 \mathrm{mM}$ ammonium formiate (only water). The ion source was operated in positive mode with a capillary voltage at $3000 \mathrm{~V}$ and detection was done in full scan from $\mathrm{m} / \mathrm{z}$ 100-1000, a peak width of $0.1 \mathrm{~min}$ and a cycle time of
$1.06 \mathrm{sec}$. HPLC-FLD was performed on a similar LC system coupled to a fluorescence detector. Water and acetonitrile were buffered with $50 \mathrm{mM}$ trifluoroacetic acid (TFA). Excitation and emission wavelengths were $333 \mathrm{~nm}$ and $460 \mathrm{~nm}$ respectively. Chemstation (Agilent) was used for data collection and evaluation. Detection was based on the extracted ion chromatogram of the ions $[\mathrm{M}+\mathrm{H}]^{+}$or $\left[\mathrm{M}+\mathrm{NH}_{3}\right]^{+}$or fluorescence emission chromatograms (Table 7). Standards were used for confirmation of identity if available. Otherwise the identity was confirmed by presence of characteristic ions or adducts in the MS spectrum and characteristic UV absorbance spectrum. Quantification of $\mathrm{FB}_{2}$ was based on a calibration curve created from dilutions of a fumonisin $\mathrm{B}_{2}$ standard $(50.1 \mu \mathrm{g} / \mathrm{ml}$, Biopure, Tulln, Austria) at levels from 0.5 to $25 \mu \mathrm{g} / \mathrm{ml}$. The remaining metabolites were semi-quantified based on peak areas, calculated in percentage of highest average peak area value of triplicates within the study.

\section{Sampling for proteome analysis}

Duplicate samples for proteome analysis were taken from surface inoculated cultures on agar plates covered with a $0.45 \mu \mathrm{m}$ polycarbonate membrane (Isopore ${ }^{\mathrm{TM}}$, Millipore). The whole mycelium mass was collected and frozen in liquid nitrogen.

\section{Protein extraction}

The method described by Kniemeyer et al. [64] with few modifications was used for protein extraction. The mycelium was homogenised with mortar and pestle under liquid nitrogen and $100 \mathrm{mg}$ of the homogenate was collected. The protein was precipitated with acetone added with $13.3 \%(\mathrm{w} / \mathrm{v})$ trichloroacetic acid and $0.093 \%$ $(\mathrm{v} / \mathrm{v}) 2$-mercaptoethanol at $-20^{\circ} \mathrm{C}$ for 24 hours followed by centrifugation at $20.000 \times \mathrm{g}$ in $15 \mathrm{~min}$ at $4^{\circ} \mathrm{C}$. Pellet was washed twice in acetone with $0.07 \%(\mathrm{v} / \mathrm{v}) 2$ mercaptoethanol and air-dried for $10 \mathrm{~min}$. Pellet was suspended in $600 \mu \mathrm{l}$ sample buffer containing $7 \mathrm{M}$ urea, $2 \mathrm{M}$ thiourea, 2\% (w/v) CHAPS, $0.8 \%(\mathrm{v} / \mathrm{v})$ ampholytes (Bio-Lyte 3/10, Bio-Rad, Hercules, California, USA), $20 \mathrm{mM}$ DTE and $20 \mathrm{mM}$ Tris (Tris-HCl buffer $\mathrm{pH}$ 7.5). The solution was incubated for 1 hour at $20^{\circ} \mathrm{C}$ and ultrasonicated for $10 \mathrm{~min}$. The sample was centrifuged at $17.000 \times \mathrm{g}$ for $30 \mathrm{~min}$, and the supernatant was collected and stored at $-80^{\circ} \mathrm{C}$. Protein concentration was determined using a 2-D Quant kit (GE Healthcare, Uppsala, Sweden).

\section{D polyacrylamide gel electrophoresis}

Isoelectric focusing was done using immobilised $\mathrm{pH}$ gradient strips $\left(11 \mathrm{~cm}, \mathrm{pH} 4-7\right.$, ReadyStrip ${ }^{\mathrm{TM}}$, Bio-Rad). A sample volume corresponding to either $40 \mu \mathrm{g}$ (image analysis gels) or $100 \mu \mathrm{g}$ (preparative gels) protein was 
Table 7: Detection parameters for selected A. niger secondary metabolites

\begin{tabular}{|c|c|c|c|c|c|c|c|}
\hline \multirow{2}{*}{\multicolumn{2}{|c|}{ Metabolite }} & \multirow{2}{*}{\multicolumn{2}{|c|}{$\begin{array}{l}\text { Detection } \\
\text { Method' }^{\prime}\end{array}$}} & \multirow{3}{*}{$\frac{\mathbf{R t}^{2}}{9.6}$} & \multicolumn{2}{|c|}{ Confirmation } & \multirow{3}{*}{$\begin{array}{l}\text { UV peak absorption wavelengths } \\
E^{3} d^{4}\end{array}$} \\
\hline & & & & & Std. & MS ions and adducts' & \\
\hline Fumonisin $B_{2}$ & {$[6]$} & MS & {$[\mathrm{M}+\mathrm{H}]^{+}=\mathrm{m} / \mathrm{z} 706$} & & $x$ & {$[\mathrm{M}+\mathrm{Na}]^{+}=\mathrm{m} / \mathrm{z} 728$} & \\
\hline Fumonisin $\mathrm{B}_{4}$ & [24] & MS & {$[\mathrm{M}+\mathrm{H}]^{+}=\mathrm{m} / \mathrm{z} 690$} & 10.5 & - & - & End $^{4}$ \\
\hline Ochratoxin A & {$[5]$} & FLD & $\begin{array}{l}\text { Excitation: } 333 \mathrm{~nm} \text {, } \\
\text { emission: } 460 \mathrm{~nm}\end{array}$ & 10.3 & $x$ & - & $\begin{array}{l}216 \mathrm{~nm}(100), 250 \mathrm{~nm}(\mathrm{sh}), 332 \mathrm{~nm} \\
(20)[69]\end{array}$ \\
\hline Ochratoxin alpha & {$[70]$} & FLD & $\begin{array}{l}\text { Excitation: } 333 \mathrm{~nm} \text {, } \\
\text { emission: } 460 \mathrm{~nm}\end{array}$ & 7.1 & $x$ & - & $\begin{array}{l}216 \mathrm{~nm}(100), 235 \mathrm{~nm}(\mathrm{sh}), 248 \mathrm{~nm} \\
\text { (sh), } 336 \mathrm{~nm}(22)[69]\end{array}$ \\
\hline Malformin $A_{1}$ & [7I] & MS & {$[\mathrm{M}+\mathrm{NH} 3]^{+}=\mathrm{m} / \mathrm{z} 547$} & 10.5 & $x$ & $\begin{array}{l}{[\mathrm{M}+\mathrm{H}]^{+}=\mathrm{m} / \mathrm{z} 530} \\
{[\mathrm{M}+\mathrm{Na}]^{+}=\mathrm{m} / \mathrm{z} 552}\end{array}$ & End $^{4}$ \\
\hline Malformin C & {$[72]$} & MS & {$[\mathrm{M}+\mathrm{NH} 3]^{+}=\mathrm{m} / \mathrm{z} 547$} & 10.9 & $x$ & $\begin{array}{l}{[\mathrm{M}+\mathrm{H}]^{+}=\mathrm{m} / \mathrm{z} 530} \\
{[\mathrm{M}+\mathrm{Na}]^{+}=\mathrm{m} / \mathrm{z} 552}\end{array}$ & End $^{4}$ \\
\hline Orlandin & [73] & MS & {$[\mathrm{M}+\mathrm{H}]^{+}=\mathrm{m} / \mathrm{z} 4 \mathrm{II}$} & 7.5 & - & {$[\mathrm{M}+\mathrm{Na}]^{+}=\mathrm{m} / \mathrm{z} 433$} & Similar to kotanin \\
\hline Desmethyl-kotanin & {$[30]$} & MS & {$[\mathrm{M}+\mathrm{H}]^{+}=\mathrm{m} / \mathrm{z} 425$} & 9.3 & - & {$[\mathrm{M}+\mathrm{Na}]^{+}=\mathrm{m} / \mathrm{z} 447$} & Similar to kotanin \\
\hline Kotanin & [30] & MS & {$[\mathrm{M}+\mathrm{H}]^{+}=\mathrm{m} / \mathrm{z} 439$} & 11.4 & $x$ & {$[\mathrm{M}+\mathrm{Na}]^{+}=\mathrm{m} / \mathrm{z} 46 \mathrm{I}$} & $\begin{array}{l}208 \mathrm{~nm}(100), 235 \mathrm{~nm}(\mathrm{sh}), 296 \mathrm{~nm} \\
\text { (sh), } 308 \mathrm{~nm}(47), 316 \mathrm{~nm} \text { (sh) [69] }\end{array}$ \\
\hline Aurasperone B & [74] & MS & {$[\mathrm{M}+\mathrm{H}]^{+}=\mathrm{m} / \mathrm{z} 607$} & 11.5 & - & {$[\mathrm{M}+\mathrm{Na}]^{+}=\mathrm{m} / \mathrm{z} 629$} & $\begin{array}{l}233 \mathrm{~nm}(68), 270 \mathrm{~nm}(\mathrm{sh}), 280 \mathrm{~nm} \\
(100), 318 \mathrm{~nm}(24), 331 \mathrm{~nm}(24) \\
404 \mathrm{~nm}(15)[75]\end{array}$ \\
\hline Pyranonigrin $\mathrm{A}$ & [76] & MS & {$[\mathrm{M}+\mathrm{H}]^{+}=\mathrm{m} / \mathrm{z} 224$} & 1.7 & - & $\begin{array}{l}{[\mathrm{M}+\mathrm{NH} 4]^{+}=\mathrm{m} / \mathrm{z} 24 \mathrm{I}} \\
{[\mathrm{M}+\mathrm{Na}]^{+}=\mathrm{m} / \mathrm{z} 246}\end{array}$ & $\begin{array}{l}210 \mathrm{~nm}(100), 250 \mathrm{~nm}(5 \mathrm{I}), 3 \mathrm{I} 4 \mathrm{~nm} \\
(68)[77]\end{array}$ \\
\hline Tensidol B & [78] & MS & {$[\mathrm{M}+\mathrm{H}]^{+}=\mathrm{m} / \mathrm{z} 344$} & 9.1 & - & {$[\mathrm{M}+\mathrm{Na}]^{+}=\mathrm{m} / \mathrm{z} 366$} & 206 nm (100), 242 nm (44) [78] \\
\hline
\end{tabular}

List of secondary metabolites included in this study with reference of their production in A. niger. Detection method and retention time, available standards used for confirmation (marked by $\mathrm{x}$ ) and additional MS and UV spectral information used for confirmation.

I) Values obtained from Antibase 2007 (Wiley, Hoboken, New jersey, USA).

2) Retention time in respective LC systems (OTA and OT-alpha analysis on separate HPLC system).

3) Parenthesis values are absorption in percent of maximum absorption, sh denotes a shoulder.

4) End: End absorption (<200 $\mathrm{nm}$ ).

diluted to a total volume of $200 \mu \mathrm{l}$ in a rehydration buffer consisting of $7 \mathrm{M}$ urea; $2 \mathrm{M}$ thiourea; $2 \%(\mathrm{w} / \mathrm{v})$ CHAPS; $0.5 \%$ (v/v) ampholytes (Bio-Lyte 3/10, BioRad); $1 \%(\mathrm{w} / \mathrm{v})$ DTT and $0.002 \%(\mathrm{w} / \mathrm{v})$ bromophenol blue. Rehydration was done at $250 \mathrm{~V}$ for 12 hours at $20^{\circ} \mathrm{C}$. Focusing was done at an increasing voltage up to $8000 \mathrm{~V}$ within $21 / 2$ hour and hold until $35 \mathrm{kVh}$ was reached, with a maximal current of $50 \mu \mathrm{A} / \mathrm{IPG}$ strip. The voltage was hold at $500 \mathrm{~V}$ until the IPG strips were frozen at $-20^{\circ} \mathrm{C}$. The IPG strips were equilibrated in buffer containing $6 \mathrm{M}$ urea, $30 \%(\mathrm{w} / \mathrm{v})$ glycerol, $2 \%(\mathrm{w} / \mathrm{v})$ SDS in $0.05 \mathrm{M}$ Tris- $\mathrm{HCl}$ buffer $\mathrm{pH}$ 8.8. First, the cysteines in the sample were reduced in equilibration buffer added with 1\% (w/v) DTT for $15 \mathrm{~min}$, and when alkylated in equilibration buffer added with $4 \%(\mathrm{w} / \mathrm{v})$ iodoacetamide for $15 \mathrm{~min}$. PAGE was done at $200 \mathrm{~V}$ in $10-20 \%$ gradient gels (Criterion Tris- $\mathrm{HCl}$ Gel, $10-$ $250 \mathrm{kD}, 13.3 \times 8.7 \mathrm{~cm}$, Bio-Rad) using an electrode buffer containing $25 \mathrm{mM}$ Tris, $1.44 \%(\mathrm{w} / \mathrm{v})$ glycine and $0.1 \%(\mathrm{w} / \mathrm{v})$ SDS. Image analysis gels were fixed in $50 \%$ (v/v) ethanol, 7\% (v/v) acetic acid two times for $30 \mathrm{~min}$ and stained over night in SYPRO Ruby Protein Gel Stain (Invitrogen, Life Technologies, Carlsbad, California, USA). The gels were washed in $10 \%(\mathrm{v} / \mathrm{v})$ ethanol, $7 \%$ $(\mathrm{v} / \mathrm{v})$ acetic acid for $30 \mathrm{~min}$. and two times in Milli-Q water (Millipore) for $5 \mathrm{~min}$. The gels were visualized with a CCD camera (Camilla fluorescence detection system, Raytest, Straubenhardt, Germany) equipped with excitation and emission filters and with an exposure time of $100 \mathrm{~ms}$. Images were saved as 16 bit tif-files. Preparative gels were fixed in $15 \%(\mathrm{w} / \mathrm{v})$ ammoniumsulphate, 2\% (v/v) phosphoric acid, 18\% (v/v) ethanol in water and stained with Coomassie Brilliant blue $(0.02 \%$ (w/v) Brilliant blue $G$ in fixing buffer) overnight and washed two times in Milli-Q water. Gels were prepared in triplicate for each biological sample for image analysis gels and a reference gel containing an equal mixture of all samples was included. A molecular weight standard (14.4 - 97.4 kDa, BioRad) was applied to the reference gel before PAGE for mass calibration.

\section{Image analysis}

Images were imported, inverted and analyzed with Imagemaster 2D platinum v. 5 (GE Healthcare). Spot detection parameters were adjusted for optimal spot detection $($ smooth $=2 ;$ min. area $=30$; saliency $=20$ ) and the spots were quantified as the relative spot volume (percent spot volume) within each gel. The spots from each gel were paired with detected spots on a reference gel containing a mixture of all samples. Matching of gels was done automatically after selection of a landmark spot in each gel.

\section{Statistical analysis}

Statistical differences in relative spot volumes between the treatments were determined by two-sided Students 
t-tests $\left(\mathrm{H}_{0}: \mu_{1}=\mu_{2}, \mathrm{H}_{\mathrm{A}}: \mu_{1} \neq \mu_{2}\right)$ using Imagemaster 2D platinum. The null hypothesis was rejected if $t_{\mathrm{df}}=2 \leq$ 4.303 (95\% confidence).

Statistical analysis of $\mathrm{FB}_{2}$ production was done using Statgraphics Plus v. 4.0 (StatPoint Inc., Herndon, Virginia, USA).

\section{Principal component analysis}

Principal component analysis was done using Unscrambler v. 8.0 (Camo Process AS, Oslo, Norway). The dataset consisted of 18 gels (samples) and 649 spots (variables) and corresponding relative spot volumes. All variables were centred and weighted by (standard deviation) $)^{-1}$. Validation was based on systematic exclusion of samples corresponding to a biological replicate.

\section{Cluster analysis}

Cluster analysis was done using the Matlab clustering algorithm "ClusterLustre" described by Grotkjær et al [36]. The relative spot volumes were transformed to Pearson distances prior to clustering (results in values between -1 and 1 , where 0 indicates the average expression level). Cluster solutions with $\mathrm{K}=3-50$ clusters were scanned with 20 repetitions. For each repetition the most likely number of clusters was determined by the Bayesian Information Criteria.

\section{In-gel digestion of proteins}

In-gel digestion was done according to Shevchenko et al. [65] with some minor modifications: The protein spots were excised from Coomassie stained gels loaded with $100 \mu \mathrm{g}$ protein. A piece of gel without staining was used as a negative control. The gel pieces were cut into approx. $1 \mathrm{~mm}^{3}$ pieces and washed twice for $15 \mathrm{~min}$., first with water and second with water/acetonitrile 1:1 (v/v). The gel particles were then washed in acetonitrile to dehydrate the gel (they shrunk and became white). A volume of $10 \mathrm{mM}$ dithiotreitol (DTT) in $100 \mathrm{mM}$ $\mathrm{NH}_{4} \mathrm{HCO}_{3}$ to cover the gel pieces was added and the proteins were reduced for $45 \mathrm{~min}$ at $56^{\circ} \mathrm{C}$. After cooling, the DTT solution was replaced by the same volume of 55 $\mathrm{mM}$ iodoacetamide in $100 \mathrm{mM} \mathrm{NH} \mathrm{NHCO}_{3}$ and the reduced proteins were alkylated for $30 \mathrm{~min}$. in the dark. The gel pieces were then washed with water, water/ acetonitrile $1: 1(\mathrm{v} / \mathrm{v})$ and acetonitrile to dehydrate the gel. Ice-cold digestion buffer containing $12.5 \mathrm{ng} / \mu \mathrm{l}$ trypsin in $50 \mathrm{mM} \mathrm{NH}_{4} \mathrm{HCO}_{3}$ was added to the gel pieces in a volume just sufficient to rehydrate the gel (5-10 $\mu \mathrm{l})$. After $45 \mathrm{~min}$ incubation on ice bath the unabsorbed digestion buffer was removed and replaced by $20 \mu \mathrm{l}$ of $50 \mathrm{mM} \mathrm{NH}_{4} \mathrm{HCO}_{3}$ buffer to cover the gel pieces. The proteins were digested overnight at $37^{\circ} \mathrm{C}$.
The buffer solution with protein digest was recovered and kept at $-20^{\circ} \mathrm{C}$.

\section{Micropurification of peptides and loading on MALDI target}

The peptide solutions were purified on nano-scale reversed-phase columns prior to mass spectrometric analysis by the method described by Gobom et al [66]. The columns were prepared by loading a few $\mu$ l slurry of a reversed phase chromatographic medium (Poros R2 $10 \mu \mathrm{m}$, Applied Biosystems) dissolved in acetonitrile into a partially constricted GelLoader pipette tip. The column was packed by applying pressure with a syringe giving a column height of $4-10 \mathrm{~mm}$ and equilibrated with $1 \%$ TFA. The peptide digest was loaded onto the column and desalted by washing with $1 \%$ TFA. The peptides were eluted with matrix solution containing $5 \mu \mathrm{g} / \mu \mathrm{l} \alpha$-cyano-4-hydroxycinnamic acid in 70\% acetonitrile and $0.1 \%$ TFA directly in one droplet onto the MALDI target (Opti-TOF ${ }^{\circledR} 384$ Well MALDI Plate Inserts, Applied Biosystems, California, USA).

\section{MALDI TOFITOF tandem MS}

MALDI peptide mass spectra and MS/MS spectra of selected peptides were obtained on a 4800 Plus MALDI TOF/TOF ${ }^{\mathrm{TM}}$ Analyzer (Applied Biosystems). External mass calibration was done using a tryptic digest of betalactoglobolin (m/z 837.48 and 2313.26) and in some cases peaks from trypsin auto-digestion peptides $(\mathrm{m} / \mathrm{z}$ 842.51 and 2211.12) were used for internal calibration of the peptide mass spectra. MS and MS/MS mass spectra were obtained at a laser intensity of 3000 and 3600 respectively. Peak lists were generated with an in house macro (in the Protein Research Group at Department of Biochemistry and Molecular Biology, University of Southern Denmark) using Data Explorer (Applied Biosystems) and converted to .mgf files containing the combined data from MS and MS/MS spectra for a sample.

\section{Protein identification}

Mascot MS/MS Ions Search (Matrix Science [67]) was used to search for matching protein sequences within the databases Swiss-Prot (Swiss Institute of Bioinformatics [37]) or NCBInr (National Center for Biotechnology Information [38]). The search parameters were: enzyme digestion with trypsin, no taxonomic restriction, carbamidomethyl (C) as fixed modification, oxidation (M) as variable modification, $[\mathrm{M}+1]^{+}$peptide charge state, monoisotopic mass values, unrestricted protein mass, $\pm 70 \mathrm{ppm}$ peptide mass tolerance, $\pm 0.6 \mathrm{Da}$ fragment mass tolerance, maximum 1 missed cleavage pr. peptide. Protein matches to Aspergillus niger proteins and with significant $(\mathrm{p}<0.05)$ Mowse Scores were regarded as 
possible candidates for identification. The candidate(s) were further inspected for number of matching peptides $(=2)$, the mass accuracy of the matching peptides, the sequence coverage and distribution of matching peptides in the obtained sequences. The reported miscleavage sites were inspected for presence of amino acids that affect the action of trypsin (proline, glutamic acid and aspartic acid or additional lysine/arginine). Finally the molecular weight and isoelectric point of the obtained protein match were compared to those observed on the gels. From samples with low intensity, peptides from keratin and trypsin were erased if necessary.

\section{Protein annotation}

Annotation of uncharacterised proteins was based on sequence similarity to characterised Swiss-Prot proteins using BlastP [40]. Proteins were given a full annotation if they had more than $80 \%$ sequence identity to a characterised Swiss-Prot protein or a putative annotation to proteins if they had $50-80 \%$ sequence identity to a characterised protein. Other proteins were assigned a "predicted" function if InterPro domains were predicted using InterProScan (European Bioinformatics Institute [41]).

\section{Authors' contributions}

LMS participated in design of the study, carried out the experimental work, the statistical and multivariate analysis and prepared the manuscript. RL participated in design of the study, contributed to the proteome analysis and revised the manuscript. MRA carried out the cluster analysis, participated in protein annotation and interpretation and revised the manuscript. PVN and JCF participated in design of the study and revision of the manuscript. All authors read and approved the final manuscript.

\section{Additional material}

\section{Additional file 1}

Protein expression data. Additional file 1.xlsx (an excel file) contains relative spot volumes for spots detected and matched to a reference gel in the $2 \mathrm{D}$ gel based proteome analysis of A. niger IBT 28144 on the three media containing 3\% starch (S), 3\% starch $+3 \%$ lactate (SL) and 3\% lactate (L). B1-B6 denotes the biological replicate, R1-R2 the electrophoresis run and Gel 1-21 the gel number.

Click here for file

[http://www.biomedcentral.com/content/supplementary/14712180-9-255-S1.ZIP]

\section{Acknowledgements}

We thank Anette Granly Koch for valuable discussions during design of the study and lb Søndergaard for reading the manuscript. We greatly acknowledge the protein research group at Department of Biochemistry and Molecular Biology, University of Southern Denmark for giving access to their instruments and especially Andrea Maria Lorentzen for excellent technical assistance. The work was supported by the Danish Research Training Council, the Technical University of Denmark and the Danish Meat Association.

\section{References}

I. Pitt JI and Hocking AD: Fungi and food spoilage London, U.K.: Blackie Academic and Professional; 1997.

2. de Vries RP and Visser J: Aspergillus enzymes involved in degradation of plant cell wall polysaccharides. Microbiol Mol Biol Rev 200I, 65:497-522.

3. Shuster E, Dunn-Coleman N, Frisvad JC and van Dijck PWM: On the safety of Aspergillus niger - a review. Appl Microbiol Biotechno 2002, 59:426-435

4. Ward OP, Qin WM, Dhanjoon J, Ye J and Singh A: Physiology and biotechnology of Aspergillus. Adv Appl Microbiol 2006, 58:1-75.

5. Abarca ML, Bragulat MR, Castellá G and Cabañes F): Ochratoxin A production by strains of Aspergillus niger var. niger. Appl Environ Microbiol 1994, 60:2650-2652.

6. Frisvad JC, Smedsgaard J, Samson RA, Larsen TO and Thrane U: Fumonisin B2 production by Aspergillus niger. J Agric Food Chem 2007, 55:9727-9732.

7. Fox EM and Howlett BJ: Secondary metabolism: Regulation and role in fungal biology. Curr Opin Microbiol 2008, I I (6):48 I-7.

8. Bayram O, Krappmann S, Ni M, Bok JW, Helmstaedt K, Valerius O, Braus-Stromeyer S, Kwon NJ, Keller NP, Yu JH and Braus GH: VelB/ VeA/LaeA complex coordinates light signal with fungal development and secondary metabolism. Science 2008, 320: I504-I506.

9. Calvo AM, Wilson RA, Bok JW and Keller NP: Relationship between secondary metabolism and fungal development. Microbiol Mol Biol Rev 2002, 66:447-459.

10. Filtenborg O, Frisvad JC and Samson RA: Specific association of fungi to foods and influence of physical environmental factors. Introduction to food- and airborne fungi Utrecht: Centraalbureau voor Schimmelcultures: Samson RA, Hoekstra ES, Frisvad JC, Filtenborg O 62002, 306-320.

II. Frisvad JC and Samson RA: Polyphasic taxonomy of Penicillium. A guide to identification of food and air-borne terverticillate Penicillia and their mycotoxins. Studies in Mycology 2004, 49: I-173.

12. Sagaram US, Kolomiets M and Shim W: Regulation of fumonisin biosynthesis in Fusarium verticillioides -maize system. Plant Path J 2006, 22:203-210.

13. Du L, Zhu X, Gerber R, Huffman J, Lou L, Jorgenson J, Yu F, ZaletaRivera $\mathrm{K}$ and Wang Q: Biosynthesis of sphinganine-analog mycotoxins. J Ind Microbiol Biotechnol 2008, 35:455-464.

14. Gutleb AC, Morrison E and Murk AJ: Cytotoxicity assays for mycotoxins produced by Fusarium strains: a review. Environ Tox Pharmcol 2002, I I:309-320.

15. Gelderblom WCA, Cawood ME, Snyman SD, Vleggaar R and Marasas WFO: Structure-activity-relationships of fumonisins in short-term carcinogenesis and cytotoxicity assays. Food Chem Toxicol 1993, 31:407-4I4.

16. Chu FS and Li GY: Simultaneous occurrence of fumonisin B-I and other mycotoxins in moldy corn collected from the Peoples-Republic-Of-China in regions with high incidences of esophageal cancer. Appl Environ Microbiol 1994, 60:847-852.

17. Marasas WFO, Jaskiewicz K, Venter FS and Van Schalkwyk DJ: Fusarium moniliforme contamination of maize in esophageal cancer areas in Transkei. S Afr Med J 1988, 74: II0-II4.

18. Sydenham EW, Thiel PG, Marasas WFO, Shephard GS, Van Schalkwyk DJ and Koch KR: Natural occurrence of some Fusarium mycotoxins in corn from low and high esophageal cancer prevalence areas of the Transkei, Southern Africa. J Agric Food Chem 1990, 38:1900-1903.

19. Yoshizawa T, Yamashita $A$ and Luo Y: Fumonisin occurrence in corn from high-risk and low-risk areas for human esophageal cancer in China. Appl Environ Microbiol 1994, 60:1626-1629.

20. Gelderblom WCA, Jaskiewicz K, Marasas WFO, Thiel PG, Horak RM, Vleggaar R and Kriek NPJ: Fumonisins - novel mycotoxins with cancer-promoting activity produced by Fusarium moniliforme. Appl Environ Microbiol I988, 54:|806-|8|I.

21. Baker SE: Aspergillus niger genomics: Past, present and into the future. Med Mycol 2006, 44:S17-S2I.

22. Pel $\mathrm{H}$, de Winde JH, Archer DB, Dyer PS, Hofmann G, Schaap PJ Turner G, de Vries RP, Albang R, Albermann K. Andersen MR, Bendtsen JD, Benen JAE, van den Berg M, Breestraat S, Caddick MX, 
Contreras R, Cornell M, Coutinho PM, Danchin EG], Debets AJM, Dekker P, van Dijck PWM, van Dijk A, Dijkhuizen L, Driessen AJM, d'Enfert C, Geysens S, Goosen C, Groot GSP, De Groot PWJ, Guillemette T, Henrissat B, Herweijer M, van den Hombergh JPTW, van den Hondel CAMJ, van der Heijden RTJM, van der Kaaij RM, Klis FM, Kools HJ, Kubicek CP, van Kuyk PA, Lauber J, Lu X, van de Maarel MJEC, Meulenberg R, Menke H, Mortimer MA, Nielsen J Oliver SG, Olsthoorn M, Pal K, van Peij NNME, Ram AFJ, Rinas U, Roubos JA, Sagt CMJ, Schmoll M, Sun JB, Ussery D, Varga J Vervecken W, van de Vondervoort PJJ, Wedler $H$, Wosten HAB, Zeng AP, van Ooyen AJJ, Visser J and Stam H: Genome sequencing and analysis of the versatile cell factory Aspergillus niger CBS 5 13.88. Nat Biotechnol 2007, 25:22I-23I.

23. Proctor RH, Brown DW, Plattner RD and Desjardins AE: Coexpression of 15 contiguous genes delineates a fumonisin biosynthetic gene cluster in Gibberella moniliformis. Fungal Genet Biol 2003, 38:237-249.

24. Noonim P, Mahakarnchanakul W, Nielsen KF, Frisvad JC and Samson RA: Fumonisin B2 production by Aspergillus niger in Thai coffee beans. Food Addit Contam 2009, 26:94-100.

25. Carberry S and Doyle S: Proteomic studies in biomedically and industrially relevant fungi. Cytotechnology 2007, 53:95-100.

26. Kim Y, Nandakumar MP and Marten MR: Proteomics of filamentous fungi. Trends Biotechnol 2007, 25:395-400.

27. Kim Y, Nandakumar MP and Marten MR: The state of proteome profiling in the fungal genus Aspergillus. Brief Func Genom Proteom 2008, 7:87-94.

28. Andersen MR and Nielsen J: Current status of systems biology in Aspergilli. Fungal Genet Biol 2009, 46:SI80-SI90.

29. Smedsgaard J: Micro-scale extraction procedure for standardized screening of fungal metabolite production in cultures. J Chromatogr A 1997, 760:264-270.

30. Hüttel $W$ and Müller M: Regio- and stereoselective intermolecular oxidative phenol coupling in kotanin biosynthesis by Aspergillus niger. Chembiochem 2007, 8:52I-529.

31. Chambers P, Issaka A and Palecek SP: Saccharomyces cerevisiae JEN I promoter activity is inversely related to concentration of repressing sugar. Appl Environ Microbiol 2004, 70:8-17.

32. Diano A, Bekker-Jensen S, Dynesen J and Nielsen J: Polyol synthesis in Aspergillus niger : Influence of oxygen availability, carbon and nitrogen sources on the metabolism. Biotechno Bioeng 2006, 94:899-908.

33. Jacobs DI, Olsthoorn MM, Maillet I, Akeroyd M, Breestraat S, Donkers S, van der Hoeven RA, van den Hondel CA, Kooistra R, Lapointe T, Menke $H$, Meulenberg $R$, Misset M, Müller WH, van Peij NN, Ram A, Rodriguez S, Roelofs MS, Roubos JA, van Tilborg MW, Verkleij AJ, Pel HJ, Stam H and Sagt CM: Effective lead selection for improved protein production in Aspergillus niger based on integrated genomics. Fungal Genet Biol 2009, 46: SI4I-SI52.

34. Kim Y, Nandakumar MP and Marten MR: Proteome map of Aspergillus nidulans during osmoadaptation. Fungal Genet Biol 2007, 44:886-895.

35. Jørgensen TR, Goosen T, Hondel CA, Ram AF and Iversen J]: Transcriptomic comparison of Aspergillus niger growing on two different sugars reveals coordinated regulation of the secretory pathway. BMC Genomics 2009, 10:44.

36. Grotkjær T, Winther $O$, Regenberg B, Nielsen I and Hansen LK: Robust multi-scale clustering of large DNA microarray datasets with the consensus algorithm. Bioinformatics 2006, 22: 58-67.

37. Swiss Institute of Bioinformatics. http://www.expasy.ch/sprot/.

38. National Center for Biotechnology Information. http://www. ncbi.nlm.nih.gov/.

39. Protein knowledgebase UniProtKB. http://www.uniprot.org/.

40. Altschul SF, Gish W, Miller W, Myers EW and Lipman DJ: Basic local alignment search tool. J Mol Biol 1990, 2I 5:403-4I0.

41. European Bioinformatics Institute. http://www.ebi.ac.uk/.

42. Shima $Y$, Shiina M, Shinozawa T, Ito $Y$, Nakajima H, Adachi $Y$ and Yabe K: Participation in aflatoxin biosynthesis by a reductase enzyme encoded by vrdA gene outside the aflatoxin gene cluster. Fungal Genet Biol 2009, 46:22I-23I.

43. Grabowska $D$ and Chelstowska A: The ALD6 gene product is indispensable for providing NADPH in yeast cells lacking glucose-6-phosphate dehydrogenase activity. J Biol Chem 2003, 278: 13984-13988.

44. Hankinson $O$ and Cove DJ: Regulation of the pentose phosphate pathway in the fungus Aspergillus nidulans. The effect of growth with nitrate. J Biol Chem 1974, 249:2344-2353.
45. Minard KI, Jennings GT, Loftus TM, Xuan D and McAlister-Henn L: Sources of NADPH and expression of mammalian NADP+specific isocitrate dehydrogenases in Saccharomyces cerevisiae. J Biol Chem 1998, 273:31486-31493.

46. Poulsen BR, Nohr J, Douthwaite S, Hansen LV, Iversen JIL, Visser and Ruijter GJG: Increased NADPH concentration obtained by metabolic engineering of the pentose phosphate pathway in Aspergillus niger. Febs Journal 2005, 272:1313-1325.

47. Fleck $C B$ and Brock M: Re-characterisation of Saccharomyces cerevisiae Achlp: Fungal CoA-transferases are involved in acetic acid detoxification. Fungal Genet Biol 2009, 46:473-485.

48. Buu LM, Chen YC and Lee FJS: Functional characterization and localization of acetyl-CoA hydrolase, Achlp, in Saccharomyces cerevisiae. J Biol Chem 2003, 278: 17203-17209.

49. Carman AJ, Vylkova S and Lorenz MC: Role of acetyl coenzyme A synthesis and breakdown in alternative carbon source utilization in Candida albicans. Eukaryotic Cell 2008, 7:|733-174I

50. Wennekes LMJ, Goosen T, Van den Broek PJM and Van den Broek HWJ: Purification and characterization of glucose-6phosphate-dehydrogenase from Aspergillus niger and Aspergillus nidulans. J Gen Microbiol 1993, I 39:2793-2800.

5I. Larochelle M, Drouin S, Robert F and Turcotte B: Oxidative stress-activated zinc cluster protein Stb5 has dual activator repressor functions required for pentose phosphate pathway regulation and NADPH production. Mol Cell Biol 2006, 26:6690-670I.

52. Li Q, Abrashev R, Harvey LM and McNeil B: Oxidative stressassociated impairment of glucose and ammonia metabolism in the filamentous fungus Aspergillus niger BI-D. Mycological Research 2008, I | 2: 1049-1055.

53. Yu J and Keller N: Regulation of secondary metabolism in filamentous fungi. Ann Rev Phytopath 2005, 43:437-458.

54. Galasinski SK, Lively TN, de Barron AG and Goodrich JA: Acetyl coenzyme A stimulates RNA polymerase II transcription and promoter binding by transcription factor IID in the absence of histones. Mol Cell Biol 2000, 20:1923-1930.

55. Shirra MK, Patton-Vogt J, Ulrich A, Liuta-Tehlivets O, Kohlwein SD, Henry SA and Arndt KM: Inhibition of acetyl coenzyme a carboxylase activity restores expression of the INOI gene in a snfl mutant strain of Saccharomyces cerevisiae. Mol Cell Bio 200I, 21:5710-5722.

56. Gardocki ME, Jani $N$ and Lopes JM: Phosphatidylinositol biosynthesis: Biochemistry and regulation. Biochimica et Biophysica Acta-Molecular and Cell Biology of Lipids 2005, 1735:89-100.

57. Simenel C, Coddeville B, Delepierre M, Latge JP and Fontaine T: Glycosylinositolphosphoceramides in Aspergillus fumigatus. Glycobiology 2008, 18:84-96.

58. Spange $\mathrm{S}$, Wagner $\mathrm{T}$, Heinzel $\mathrm{T}$ and Kramer $\mathrm{OH}$ : Acetylation of non-histone proteins modulates cellular signalling at multiple levels. Int J Biochem Cell Biol 2009, 4I:185-198.

59. Roze LV, Arthur AE, Hong S, Chanda A and Linz JE: The initiation and pattern of spread of histones $\mathrm{H} 4$ acetylation parallel the order of transcriptional activation of genes in the aflatoxin cluster. Mol Microbiol 2007, 66:7I3-726.

60. Shwab EK, Bok JW, Tribus M, Galehr J, Graessle S and Keller N: Histone deacetylase activity regulates chemical diversity in Aspergillus. Eukaryotic Cell 2007, 6:1656-1664.

61. Kim H and Woloshuk CP: Role of AREA, a regulator of nitrogen metabolism, during colonization of maize kernels and fumonisin biosynthesis in Fusarium verticillioides. Fungal Genet Biol 2008, 45:947-953.

62. Bluhm BH and Woloshuk CP: Amylopectin induces fumonisin B-I production by Fusarium verticillioides during colonization of maize kernels. Mol Plant Microbe Interact 2005, 1 8:1333-1339.

63. Keyser Z, Vismer HF, Klaasen JA, Snijman PW and Marasas WFO: The antifungal effect of fumonisin B-I on Fusarium and other fungal species. S Afr J Sci 1999, 95:455-458.

64. Kniemeyer $O$, Lessing $F$, Scheibner $O$, Hertweck $C$ and Brakhage AA: Optimisation of a 2-D gel electrophoresis protocol for the human-pathogenic fungus Aspergillus fumigatus. Curr Genet 2006, 49:178-189.

65. Shevchenko A, Wilm M, Vorm $O$ and Mann M: Mass spectrometric sequencing of proteins from silver stained polyacrylamide gels. Anal Chem 1996, 68:850-858.

66. Gobom J, Nordhoff E, Mirgorodskaya E, Ekman R and Roepstorff P. Sample purification and preparation technique based on nano-scale reversed-phase columns for the sensitive analysis of complex peptide mixtures by matrix-assisted laser 
desorption/ionization mass spectrometry. J Mass Spectrom 1999, 34:105-1 I6.

67. Matrix Science. http://www.matrixscience.com/.

68. Andersen MR, Nielsen ML and Nielsen J: Metabolic model integration of the bibliome, genome, metabolome and reactome of Aspergillus niger. Mol Sys Biol 2008, 4:178.

69. Nielsen KF and Smedsgaard J: Fungal metabolite screening: database of $\mathbf{4 7 4}$ mycotoxins and fungal metabolites for dereplication by standardised liquid chromatography-UVmass spectrometry methodology. J Chromatogr A 2003, I002: III-136.

70. Varga J, Rigó $\mathrm{K}$ and Téren J: Degradation of ochratoxin A by Aspergillus species. Int J Food Microbiol 2000, 59:I-7.

71. Kim K, Sugawara F, Yoshida S, Murofushi N, Takahashi N and Curtis RW: Structure of malformin A, a phytotoxic metabolite produced by Aspergillus niger. Biosci Biotechnol Biochem 1993, $57: 240-243$.

72. Kobbe B, Cushman M, Wogan GN and Demain AL: Production and antibacterial activity of malformin $C$, a toxic metabolite of Aspergillus niger. Appl Environ Microbiol 1977, 33:996-997.

73. Cutler HG, Crumley FG, Cox RH, Hernandez O, Cole RJ and Dorner JW: Orlandin: A nontoxic fungal metabolite with plant growth inhibiting properties. J Agric Food Chem 1979, 27:592-595.

74. Akiyama K, Teraguchi S, Hamasaki Y, Mori M, Tatsumi K, Ohnishi K and Hayashi $\mathrm{H}$ : New dimeric naphthopyrones from Aspergillus niger. J Nat Prod 2003, 66:136-139.

75. Priestap HA: New naphthopyrones from Aspergillus fonsecaeus. Tetrahendon 1984, 40:3617-3624.

76. Hiort J, Maksimenka K, Reichert M, Perovic-Ottstadt S, Lin $\mathrm{WH}$, Wray V, Steube K, Schaumann K, Weber H, Proksch P, Ebel R, Muiller WEG and Bringmann G: New natural products from the sponge-derived fungus Aspergillus niger. J Nat Prod 2004, 67:1532-1543.

77. Schlingmann G, Taniguchi T, He H, Bigelis R, Yang HY, Koehn FE, Carter GT and Berova N: Reassessing the structure of pyranonigrin. J Nat Prod 2007, 70: | |80-| |87.

78. Fukuda T, Hasegawa Y, Hagimori K, Yamaguchi Y, Masuma R, Tomoda $H$ and Õmura S: Tensidols, new potentiators of antifungal miconazole activity, produced by Aspergillus niger FKI-2342. J Antibiot 2006, 59:480-485.

Publish with BioMed Central and every scientist can read your work free of charge

"BioMed Central will be the most significant development for disseminating the results of biomedical research in our lifetime. "

Sir Paul Nurse, Cancer Research UK

Your research papers will be:

- available free of charge to the entire biomedical community

- peer reviewed and published immediately upon acceptance

- cited in PubMed and archived on PubMed Central

- yours - you keep the copyright

Submit your manuscript here:

http://www.biomedcentral.com/info/publishing_adv.asp
BioMedcentral 